\title{
The Effect of Riddles on Problem Solving Skills of 57-66 Months Old Children
}

Beyza DEMIREL $^{\mathrm{a}^{*}}$ (ORCID ID - 0000-0002-5741-623X)

Ebru DERETARLA GÜL ${ }^{\mathrm{b}}$ (ORCID ID - 0000-0002-6241-8109)

${ }^{a}$ Hacettepe Üniversitesi, Eğitim Fakültesi, Ankara/Türkiye

${ }^{b}$ Çukurova Üniversitesi, Eğitim Fakültesi, Adana/Türkiye

\section{Article Info}

DOI: $10.14812 /$ cufej.943800

\section{Article history:}

Received 27.05.21

Revised 08.10.21

Accepted 22.10.21

Keywords:

Riddles,

Preschool,

Problem solving skills.

\section{Abstract}

In this study, it was aimed to examine the effect of riddles on the problem-solving skills of 57-66 months old children. The study group consists of 32 children studying in the kindergarten of 2 different private schools in the city center of Mus in the 2020-2021 academic year. The model of the research is the pretest-posttest unequalized group design, which is one of the weak experimental designs. During the data collection process, the "General Information Form" created by the researcher, containing personal information about parents and their children, and the "Teacher Information Form" to obtain information about the children's teachers were used. In the study, the "Problem Solving Skills Scale (PSSS)" developed by Oguz and Koksal-Akyol (2015) was used for the experimental and control groups to measure the problem-solving skills of the children. During the application process, 16 riddle activities developed by the researcher were applied to the experimental group for eight weeks. As a result of the findings of the research, it was concluded that riddles were effective on problem solving skills.

\begin{tabular}{|c|c|}
\hline \multicolumn{2}{|c|}{ Bilmecelerin 57-66 Aylık Çocukların Problem Çözme Becerilerine Etkisi } \\
\hline Makale Bilgisi & Öz \\
\hline DOI: 10.14812/cufej.943800 & $\begin{array}{l}\text { Bu araştırmada, 57-66 aylık çocukların problem çözme becerileri üzerinde bilmece } \\
\text { etkinliklerinin etkisinin incelenmesi amaçlanmıştır. Çalışma grubunu, 2020-2021 }\end{array}$ \\
\hline Makale Geçmişi: & eğitim- öğretim yılında Muş ili merkezinde 2 farklı özel okulun anasınıfında öğrenim \\
\hline Geliş $\quad 27.05 .21$ & gören 32 çocuk oluşturmaktadır. Araştırmanın modeli ön test-son test \\
\hline Düzeltme & denkleştirilmemiş gruplu yarı deneysel desendir. Veri toplama sürecinde araştırmacı \\
\hline Kabul $\quad 22.10 .21$ & tarafından oluşturulan, ebeveynler ve çocukları hakkında bilgi edinmek amacıyla kişisel \\
\hline \multirow{2}{*}{$\begin{array}{l}\text { Anahtar Kelimeler: } \\
\text { Bilmece, } \\
\text { Okul öncesi, } \\
\text { Problem çözme becerisi. }\end{array}$} & $\begin{array}{l}\text { bilgilerin bulunduğu "Genel Bilgi Formu" ve çocukların öğretmenleri hakkında bilgi } \\
\text { edinmek amacıyla "Öğretmen Bilgi Formu" kullanılmıştır. Araştırmada çocukların } \\
\text { problem çözme becerilerini ölçmek için deney ve kontrol gruplarına Oğuz ve Köksal- }\end{array}$ \\
\hline & $\begin{array}{l}\text { Akyol (2015)'un geliştirdiği “Problem Çözme Becerisi Ölçeği (PÇBÖ)" kullanılmıştır. } \\
\text { Uygulama sürecinde deney grubuna araştırmacı tarafından geliştirilen sekiz hafta } \\
\text { süresince } 16 \text { bilmece etkinliği uygulanmıştır. Araştırma elde edilen bulgular sonucunda } \\
\text { bilmece etkinliklerinin problem çözme becerileri üzerinde etkili olduğu sonucuna } \\
\text { ulaşılmıştır. }\end{array}$ \\
\hline
\end{tabular}

\section{Introduction}

Since the preschool period is a period in which different developmental areas are most affected by each other and the child develops quite rapidly compared to other life periods, the education to be given to children in this period should support their development in accordance with their needs (Kandır

*This article is derived from Beyza Demirel's master's thesis titled "The Effect of Riddles on the Problem Solving Skills of 57-66 Months-old Children" conducted under the supervision of Doç. Dr. Ebru Deretarla Gül.

* Author: beyza_demirel@hacettepe.edu.tr 
\& Alpan, 2008; MEB, 2013; Oktay, 2007). In the preschool education process, the teacher provides the child with qualified cognitive stimuli and rich language interactions through activities, helping the child to discover their own abilities (Katrancl, 2018; MEB, 2013). One of these types of activities is language activities (MEB, 2013). Language activities are activities that plan to improve children's correct and beautiful speech, improve their vocabulary and increase their communication skills. While planning language activities, different methods and techniques should be used by preschool teachers, and the educational environment should be arranged accordingly, taking into account the developmental period of the children (MEB, 2013).

Riddle activities, which are one of the language activities included in the preschool education process and which children participate with pleasure, are one of the teaching tools that support children's language development and vocabulary (Alan, 2019; Balta, 2013). Riddles as a teaching tool; It can be used to concretize concepts in the mind, to reveal similarities and differences, to follow inductive ways to find the answer, and in a question-answer strategy (Balta, 2013). The most obvious feature of riddles whose answers are hidden or implicitly presented is that they create confusion. Using unconventional similes in the process of finding the hidden improves the cognitive thinking skills of the child by overturning quick thinking and familiar ways of thinking (Abrahams \& Dundes, 2007 as cited in Balta, 2013; Stefanova, 2007).

When the literature was examined, it was seen that there were studies on riddles and the importance of riddles. These studies focused on the ability to understand riddles (Belanger, Kirkpatrick, \& Derks, 1998; Binsted, Pain, \& Ritche, 1997; Dowling, 2014; Ely \& McCabe, 1994; Ezell \& Jarzynka, 1996; Firestien \& Mccowan, 1988; Goldstein, Harman, Mcghee. \& Karasik, 1975; Guo, Zhang, Wang, and Xeromeritou, 2011; Korovkin and Nikiforova, 2015; Mai, Luo, Wu, and Luo, 2004; Pepicello, 1989; Smullyan, 1978; Stefanova, 2007; Sutton-Smith, 1973; Van Dooren, Lem, De Wortelaer, \& Verschaffel, 2019; Waithaka, 2017; Whitt \& Prentice, 1977), language learning (Erkan, 2015; Lee, 2019; Mert, 2012; Özkara, 2013; Yılmaz \& Taşkın, 2014), language development (Ruiz Gurillo, 2017; Taner Derman, Ergişi Birgül, \& Şahin Zeteroğlu, 2019), teaching vocabulary (Erdoğan, Altınkaynak \& Erdoğan, 2013; Karayazı \& Karakuş, 2018; Oruç, 2011), giving children a love of mother tongue (Yangil \& Kerimoğlu, 2014) ), cognitive development (Baker, 2017; Birgül \& Akyol, 2018; Çobanoğlu, 2017; Ersoy, 1986; Guo, Zhang, Whang, Xeromeritou, 2011; Montalvo-Castro, 2011; Motroni, 2016; Taşkın \& Tuğrul, 2014) and concept development (Hayran, 2010) and that riddles can be used as a teaching tool (Keleş, 2007). When the related studies were examined, it was seen that the studies on the use of riddles in the preschool education process were mostly of foreign origin. Although the importance of riddles in pre-school education was expressed in domestic studies, it was seen that studies on riddles were limited.

In the study conducted by Gönen et al. (2010), it was seen that preschool teachers included riddles in preparation for language activities or as asking riddles about the story. In the study, it was stated that riddles were one of the least used activities by teachers. It was thought that the reason for this was that the teachers had difficulty in finding suitable riddles for the study to be done, since they mostly presented the riddles in preparation for another language activity. In the study conducted by TepetaşCengiz et al. (2018), in which the language activities included in the preschool teachers' plans and their views on these activities were examined, the teachers stated that they used riddles two or three times a week to attract attention and warm up before the language activities.

When the studies on riddles are examined, it is seen that riddles are included in other activities besides language activities in pre-school education. Altun and Tantekin-Erden (2016) aimed to examine students' views on early literacy in their study with students studying in the preschool teaching department. In the findings they obtained as a result of the study, it was seen that the pre-service teachers included riddles as an activity to support early literacy. Tuğrul et al (2014) stated that in their study examining the opinions of six-year-old children and their teachers about game activities, teachers included riddles as game activities. Erdoğan et al., 2013), when they examined the reading and writing preparation activities of preschool teachers, stated that the teachers did not include riddles as a 
DEMIREL \& DERETARLA GÜL- Çukurova Üniversitesi Eğitim Fakültesi Dergisi, 50(2), 2021, 721-748

separate activity, but included them during transition activities. Compared to the studies in the literature, in which the opinions of teachers or teacher candidates are mostly taken about riddles, Ergişi (2014), in his study aiming to examine the effects of language activities on the development of preschool children, included riddles as asking children to riddles, finding the answer with clues or creating riddles with children.

Based on the relationship between riddles and cognitive development in the preschool period, we can actually think of it as a kind of cognitive gymnastics, as it encourages children to think and supports children to look at these points more carefully by emphasizing the most striking points of the concept in the riddle (Çelebioğlu \& Öksün, 1995; cited in Kabadayı, 2007). In addition, riddles are also very important in terms of cognitive development as they include all stages of cognitive domain steps (Kabadayı, 2007). Guo et al. (2011) also included riddles within the scope of humor activities and stated that humor activities are closely related to cognitive development. Riddles, which are related to cognitive development, are also directly related to problem solving skills by developing associative and creative thinking, analyzing, connecting concepts and events, creating cause-effect relationships (Altunbay, 2014; Sarıca, Aksu, \& Yurdakul, 2012).

Ely and McCabe (1994) stated in their study that about a quarter of kindergarten children's daily expressions involve some form of language play, including riddles and other humor types. As stated before, riddles, which are a question-answer method and also a language game, can be considered as problems that can be solved especially for 5-6 year old children (Doolittle, 1995; Guo, Zhang, Whang, \& Xeromeritou, 2011). Pepicello (1989) defined riddles in his study as a kind of 'linguistic problems' in which a problem is intended to be solved by the respondent. What is emphasized in this study is that an individual's success in solving the riddle depends on his ability to specifically keep in mind an ambiguous language problem and to solve it with a unique solution.

While it is supported in the literature that including riddles in preschool education is effective on problem solving skills (Balta, 2013; Kılıçarslan, 2015; MEGEP, 2016); Studies on the relationship between riddle and problem solving skills are mostly of foreign origin (Belanger, Kirkpatrick, \& Derls, 1998; Dewi \& Bektiarso, 2017; Doolittle, 1995; Firestien \& Mccowan, 1988; Goldstein, Harman, Mcghee, \& Karasik, 1975; Guo , Zhang, Wang, \& Xeromeritou, 2011; Himah, Bektiarso, and Prihandono, 2015; Korovkin and Nikiforoya, 2015; Masfuah, 2016; Smullyan, 1978; Van Dooren, Lem, Lem, S., De Wortelaer, \& Verschaffel, 2019; Waithaka, 2017; Yuill, 2009), it has been seen that the studies conducted in the country are mainly done at the primary school level (Karadeniz, 2018).

Based on all of these; The question of "Are riddles effective on problem solving skills of 57-66 month old children?" was determined as the problem of the research.

In line with the general problem of the research, answers were sought for the following subproblems:

1. Is there a significant difference between the averages of the "PSSS" post-test scores corrected according to the "PSSS" pre-test scores of the children in the experimental and control groups?

2. Is there a significant difference between the pretest, posttest and retention scores of the children in the experimental group?

3. Is there a significant difference between the scores of the children in the experimental group in the "PSSS" post-test-permanence test?

\section{Method}

\section{Research Model}

The model of this research, which aims to examine the effect of riddle activities on the problem solving skills of 57-66 month-old children, is the pretest-posttest unequalized group design, which is one of the weak experimental designs. In this design, the measurements of the dependent variable (the 
DEMIREL \& DERETARLA GÜL- Çukurova Üniversitesi Eğitim Fakültesi Dergisi, 50(2), 2021, 721-748

scores obtained from the Problem-Solving Skills Scale (PSSS) are obtained from the research group before the application. "In this design, in which random assignment is not possible, ready-made groups are used and these pattern groups (experiment-control) allow the starting points of the groups to be known about the measured variable, thus measuring the change" (Büyüköztürk, Kılıç-Çakmak, Akgün, Karadeniz, \& Demirel, 2012). In this study, riddle activities constitute the independent variable of the research, and the scores obtained from the PSSS applied to 57-66 month-old children constitute the dependent variable of the research.

Table 1.

Experimental Design

\begin{tabular}{ccccc}
\hline Group & Pre-Test & Process & Post-Test & Permanence Test \\
\hline EG & $\mathrm{M}_{1}$ & Riddles Activities & $\mathrm{M}_{3}$ & $\mathrm{M}_{5}$ \\
& & + & \\
& MEB (2013) Preschool \\
& Education Program & \\
& & MEB (2013) Preschool & $\mathrm{M}_{4}$ \\
& $\mathrm{M}_{2}$ & Education Program & \\
& &
\end{tabular}

EG; Experimental Group,

CG; Control Group

$M_{1}-M_{3}-M_{5}$; Pretest-posttest-permanence test measurements applied to the experimental group,

$M_{2}-M_{4}$; It refers to the pretest-posttest measurements applied to the control group.

\section{Study Group}

The study group of the research consists of 32 children studying in two kindergartens in two different private schools affiliated to the Ministry of National Education in the province of Muş in the 2020-2021 academic year. There are 16 children in the experimental group and 16 children in the control group. The Language-Cognitive Development section of the Ankara Developmental Screening Inventory (AGTE) was used to determine whether the language-cognitive development of the children in the experimental and control groups showed normal development. According to the results of the scores obtained from the inventory, it was seen that the language-cognitive development levels of the children in both groups were at a normal level.

The fact that the groups did not interact with each other, that they did not participate in a similar study before, socioeconomic status, age and language development characteristics of the groups were taken into account in the determination of the schools forming the study group. Table 2 presents information about the study group. 
Table 2.

Demographic Characteristic of the Study Group

\begin{tabular}{|c|c|c|c|}
\hline \multicolumn{4}{|c|}{ Gender } \\
\hline Group & Gender & $f$ & $\%$ \\
\hline \multirow[t]{3}{*}{ Experimental } & Female & 9 & 56.25 \\
\hline & Male & 7 & 43.75 \\
\hline & Total & 16 & 100.0 \\
\hline \multirow[t]{3}{*}{ Control } & Female & 11 & 68.75 \\
\hline & Male & 5 & 31.25 \\
\hline & Total & 16 & 100.0 \\
\hline \multicolumn{4}{|c|}{ Monthly Averages } \\
\hline Group & Monthly Averages & $f$ & $\%$ \\
\hline Experimental & $56-66$ & 16 & 100.0 \\
\hline Control & $56-66$ & 16 & 100.0 \\
\hline \multicolumn{4}{|c|}{ Number of Siblings } \\
\hline Group & Number of Siblings & $f$ & $\%$ \\
\hline \multirow[t]{4}{*}{ Experimental } & .00 & 8 & 50.0 \\
\hline & 1.00 & 7 & 43.75 \\
\hline & 2.00 & 1 & 6.25 \\
\hline & Total & 16 & 100.0 \\
\hline \multirow[t]{6}{*}{ Control } & .00 & 5 & 31.25 \\
\hline & 1.00 & 4 & 25.0 \\
\hline & 2.00 & 2 & 12.5 \\
\hline & 3.00 & 3 & 18.75 \\
\hline & 4.00 & 2 & 12.5 \\
\hline & Total & 16 & 100.0 \\
\hline \multicolumn{4}{|c|}{ Mother Education Status } \\
\hline Group & Mother Education Status & $f$ & $\%$ \\
\hline \multirow[t]{3}{*}{ Experimental } & High School & 4 & 25.0 \\
\hline & University & 12 & 75.0 \\
\hline & Total & 16 & 100.0 \\
\hline \multirow[t]{4}{*}{ Control } & Middle School & 1 & 6.0 \\
\hline & High School & 6 & 38.0 \\
\hline & University & 9 & 56.0 \\
\hline & Total & 16 & 100.0 \\
\hline \multicolumn{4}{|c|}{ Father Education Status } \\
\hline Group & Father Education Status & $f$ & $\%$ \\
\hline \multirow[t]{3}{*}{ Experimental } & High School & 2 & 13.0 \\
\hline & University & 14 & 87.0 \\
\hline & Total & 16 & 100.0 \\
\hline \multirow[t]{3}{*}{ Control } & High School & 4 & 25.0 \\
\hline & University & 12 & 75.0 \\
\hline & Total & 16 & 100.0 \\
\hline
\end{tabular}

According to Table 2, there were 9 girls (56.25\%), 7 boys (43.75\%) in the experimental group, 11 girls $(68.75 \%)$ and 85 boys (31.25\%) in the control group. Among the children in the experimental group, there were $8(50.0 \%)$ children with only one child, $7(43.75 \%)$ with one sibling, and $1(6.25 \%)$ child with two siblings. Among the children in the control group, there were only $5(31.25 \%)$ children, $4(25.0 \%)$ children with one sibling, 2 (12.5\%) with two siblings, $3(18.75 \%)$ with three siblings, and $2(12.5 \%)$ 
children with four siblings. is seen. Considering the educational status of the mothers of the children in the experimental group, it is seen that $4(25.0 \%)$ people are high school and $12(75.0 \%)$ are university students. The maternal education levels of the children in the control group were found to be $1(6.0 \%)$ middle school, 6 (38.0\%) high school and 9 (56.0\%) university students. Considering the father's educational status of the children in the experimental group, it is seen that $2(13.0 \%)$ people are high school and 14 (87.0\%) people are university. When the father education status of the children in the control group is examined, it is seen that $4(25.0)$ people are high school and $12(75.0 \%)$ are university.

Table 3.

Demographic Information on Children's Teachers

\begin{tabular}{|c|c|c|c|c|}
\hline Group & Gender & Education Level & $\begin{array}{l}\text { Undergraduate } \\
\text { Graduation Area }\end{array}$ & $\begin{array}{c}\text { Professional } \\
\text { Seniority Year }\end{array}$ \\
\hline Experimental & Female & Bachelor's Degree & $\begin{array}{l}\text { Early Childhood } \\
\text { Education }\end{array}$ & 3 \\
\hline Control & Female & Bachelor's Degree & $\begin{array}{l}\text { Early Childhood } \\
\text { Education }\end{array}$ & 5 \\
\hline
\end{tabular}

As seen in Table 3, the gender of the teachers of the children in the experimental and control groups is female and their education level is undergraduate. It is seen that the undergraduate graduation area of the experimental group teacher is pre-school education, while the control group teacher is a child development graduate. In addition, it is seen that the professional seniority year of the experimental group teacher is 3 years, and the control group teacher is 5 years.

\section{Instruments}

In the study, the General Information Form developed by the researcher was used to obtain information about the children in the experimental and control groups and their families. Teacher Information Form prepared by the researcher was used for the preschool education teachers of the children in the experimental and control groups. As a pre-test, post-test and retention test for the experimental group; On the other hand, the "Problem Solving Skills Scale (PSSS)" developed by Oğuz and Köksal-Akyol (2015) was administered by the researcher as a pre-test and post-test to the control group.

\section{General Information Form}

General Information Form prepared by the researchers was applied to the parents before the pretest was applied to obtain information about the children in the experimental and control groups themselves and their families. In the general information form, questions about the birth dates, gender and number of siblings of the children included in the experimental and control groups were included. In the form, questions about the parents' educational status were also included for the parents of the children.

\section{Teacher Information Form}

Teacher Information Form was applied to the preschool education teachers of the children in the experimental and control groups. In the form prepared by the researcher, questions about the gender, education status, undergraduate graduation fields and professional seniority of the children in the experimental and control groups were included. The form was applied to the teachers by the researcher before the pre-test was applied.

\section{Problem Solving Skills Scale (PSSS)}

In the study, the "Problem Solving Skills Scale (PSSS)" developed by Oğuz and Köksal-Akyol (2015) was used to determine the problem solving skill scores of the children in the experimental and control groups. There are 18 different problem situations and drawings related to this problem situation in the scale. In the PSSS, which is prepared as a five-point Likert type scale, scores between 0 and 4 are taken for the solution produced for each problem situation. The range of scores to be taken from the PSSS is 0- 
DEMIREL \& DERETARLA GÜL- Çukurova Üniversitesi Eğitim Fakültesi Dergisi, 50(2), 2021, 721-748

72. According to Oğuz and Köksal-Akyol (2015), the important thing in PSSS is that the child can produce more alternative solutions and questions are a tool. It does not matter from which questions the child's answers come from, the goal is the number of answers.

The validity of the "Problem Solving Skills Scale" developed by Oğuz and Köksal-Akyol (2015) was determined by applying the content validity index (CGI) and exploratory factor analysis (EFA). CGI .99 for the compliance level of the items; The CGI was calculated as .96 for the compliance level of the items with the drawings. "These values mean that all items in the scale are necessary and that the scale as a whole provides content validity" (Oğuz \& Köksal-Akyol, 2015). As a result of the EFA applied to the PBCS, it was concluded that the scale had one factor. This factor explains $30.68 \%$ of the total variance of the scale. In single-factor scales, it is sufficient for the variance to be $30 \%$ or more (Büyüköztürk, 2010). In addition, Cronbach Alpha reliability coefficient in terms of internal consistency and reliability coefficient in terms of Test-Retest Stability were calculated for the reliability study of the scale, and this value was found to be .86. For a Likert-type scale, it can be said that the reliability of this scale is high (Tezbaşaran, 1997 as cited in Oğuz \& Köksal-Akyol, 2015).

\section{Data Collection}

The necessary research permissions were obtained before the actual application process of the research, which was carried out in two private kindergartens in the province of Muş and affiliated to the Ministry of National Education. The pilot application of the study was carried out in February-March in the 2019-2020 academic year. During the pilot implementation process, 12 activities were implemented and the familiarity of the children with the concepts in the riddles included in these activity plans, the process of solving the riddle, and the attainment of the outcome indicators included in the activity plans at the end of the process were observed. At the end of the pilot application process, it was seen that some riddles belong to concepts that the children did not know, and therefore some riddle activities were changed. The questions and activities included in the process of solving the riddle were diversified and arranged in a way to reach the gains and indicators in the plan.

A total of 16 riddle activities were applied to the experimental group of the study two days a week for eight weeks. While preparing the 16 activity plans, the achievements and indicators included in the 2013 Pre-School Education Program prepared by the Ministry of National Education were taken into consideration. While choosing the riddles to be asked to the children, attention was paid to ensure that the riddles belong to concrete concepts. While planning the activities, it was ensured that the children reached the answers to the riddles by going through a problem-solving process. In the activities, clues, picture cards and puzzles were prepared regarding the riddle in the activity plan of that day, and it was supported that the children could reach the answer to the riddle. For the activity plans, expert opinion was first taken and rearranged in line with expert opinion. The pilot application was carried out before the actual application, the necessary arrangements were made after the application, it was presented to the expert opinion again and the final version was given. The activities, which lasted approximately 2035 minutes, were implemented by the researcher; Since video recording is not allowed, only photographs were taken and the event process was audio recorded. At the end of each activity, evaluation questions were asked for the children to express their views on the activity process.

\section{Ethics Committee Permission Information}

Name of the committee that made the ethical evaluation: Cukurova University, Social Sciences Institute Ethics Committee

Date of ethical evaluation decision: 28.01.2020

Ethics assessment document number: 75137396-199 


\section{Data Analysis}

The data collected during the research process were analyzed using the SPSS 26.0 program. The normal distribution of the scores of the children in the experimental and control groups from the PSSS (pretest-posttest-permanence test) was examined with the Shapiro-Wilk Test, since the sample size was less than 50 (Büyüköztürk, 2010). The Shapiro-Wilk Test was applied to determine the arithmetic mean, minimum, kurtosis, standard deviation, maximum values of the data belonging to the groups, skewness and whether the distribution was normal. The results of the analyzes performed are shown in Table 4-56.

Table 4.

Descriptive Statistical Values of Experimental and Control Groups PSSS Pre-Test Measurements and Normality Test Results

\begin{tabular}{lcccccccc}
\hline Group & $\mathbf{N}$ & $\overline{\mathbf{X}}$ & Sd & Min & Max & Skewness & Kurtosis & Shapiro-Wilk Test \\
\hline Experimental & 16 & 36.63 & 11.95 & 23.00 & 62.00 & .960 & .186 & .073 \\
Control & 16 & 34.63 & 11.87 & 22.00 & 63.00 & 1.050 & .875 & .053 \\
\hline
\end{tabular}

As can be seen in Table 4, the pre-test mean scores of the groups from the PSSS pre-test application were 36.63 in the experimental group and 34.63 in the control group. From this point of view, it can be said that the pre-test measurements of PSSS are close to each other for the experimental and control groups. When the skewness and kurtosis values of the groups are examined, it can be said that the values range from -1.96 to +1.96 , which is the standard value, and that the scores show a normal distribution (Field, 2009). In addition, the PSSS pre-test Shapiro-Wilk Test results of the experimental and control groups also show that the distribution is normal ( $p>.05)$.

Table 5.

Descriptive Statistical Values of Experimental and Control Groups PSSS Post-Test Measurements and Normality Test Results

\begin{tabular}{lcccccccc}
\hline Group & $\mathbf{N}$ & $\overline{\mathbf{X}}$ & Sd & Min & Max & Skewness & Kurtosis & Shapiro-Wilk Test \\
\hline Experimental & 16 & 44.19 & 8.30 & 33.00 & 61.00 & .760 & .092 & .287 \\
Control & 16 & 37.00 & 10.32 & 20.00 & 56.00 & .031 & -.365 & .877 \\
\hline
\end{tabular}

As seen in Table 5, the post-test mean scores of the groups from the PSIS post-test measurements were 44.19 in the experimental group and 37.00 in the control group. While the smallest value taken from the scale in the experimental group was 33.00, the maximum value was 61.00 , the smallest value taken from the scale was 20.00 and the highest value was 56.00 in the control group. When the skewness and kurtosis values of the groups are examined, it can be said that the values range from -1.96 to +1.96 , which is the standard value, and that the scores show a normal distribution (Field, 2009). In addition, the results of the PSSS post-test Shapiro-Wilk Test belonging to the experimental and control groups also show that the distribution is normal $(p>.05)$.

Table 6.

Descriptive Statistical Values of Experimental Group PSSS Retention Test Measurements and Normality Test Results

\begin{tabular}{ccccccccc}
\hline Group & $\mathbf{N}$ & $\overline{\mathbf{X}}$ & Sd & Min & Max & Skewness & Kurtosis & Shapiro-Wilk Test \\
\hline Experimental & 16 & 42.8125 & 8.76522 & 26.00 & 61.00 & .422 & .486 & .541
\end{tabular}

As is seen in Table 6, the skewness (.422) and kurtosis (.486) values are at the $5 \%$ significance level, the standard value is between -1.96 and +1.96 , and the scores show a normal distribution (Field, 2009). The value obtained from the Shapiro-Wilk Test in Table 15 indicates that the values obtained from the permanence test show a normal distribution $(p>0.05)$. It was determined that the post-test and retention test scores of the experimental group showed normal distribution. 
DEMIREL \& DERETARLA GÜL- Çukurova Üniversitesi Eğitim Fakültesi Dergisi, 50(2), 2021, 721-748

ANCOVA, ANOVA for Single Factor Repeated Measurements, Paired Sample T Test were used to test the sub-problems of the research. When the pretest scores of both groups were controlled, ANCOVA analysis was used to calculate the posttest scores. Before making ANCOVA analysis, assumptions of normality of distribution, equality of regression tendency and homogeneity of variances between groups were tested for the experimental and control groups, and ANCOVA analysis was used because these assumptions were provided for the results obtained. For the ANCOVA analysis, first of all, the assumptions necessary for the analysis were checked (Pallant, 2017). One of the assumptions is that the covariates are measured before the application. This assumption is provided because the PSSS applied to the experimental and control groups was applied before the application. Another assumption is the reliability of covariates. Since the Cronbach's alpha value, which should be at least .70, is .86 for the PSSS, this assumption was provided.

Another assumption is that there is a linear relationship between the dependent variable and the covariate for all groups. The linearity of the relations between the pre-test and post-test PSSS scores of the groups can be seen in Figure 1 and Figure 2.

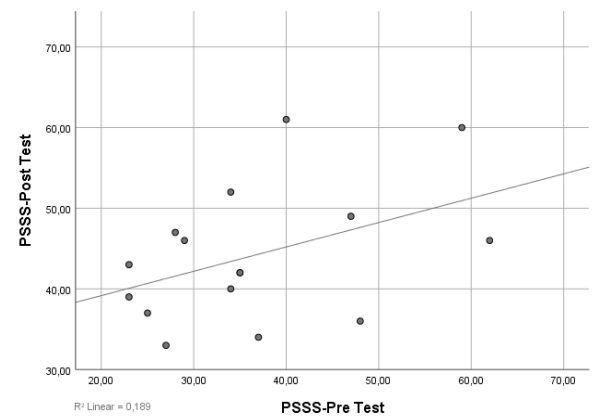

Figure 1. The Scattering Diagram Showing the Linear Relationship Between the Experimental Group's PSSS Pre-Test and Post-Test Scores

As seen in Figure 1, there is a linear relationship between the pretest and posttest scores of the experimental group.

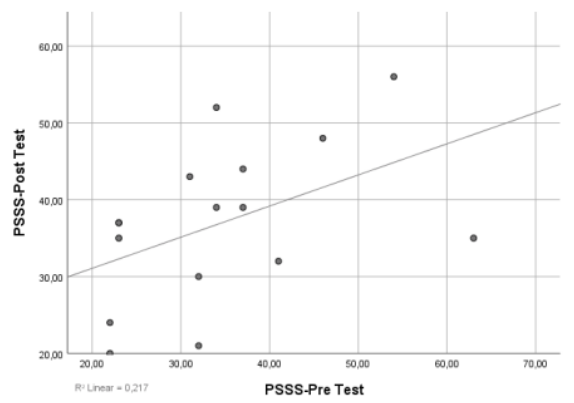

Figure 2. Scattering Diagram Showing the Linear Relationship Between Control Group PSSS Pre-Test and Post-Test Scores

According to Figure 2, there is a linear relationship between the control group's PSSS pre-test and PSSS post-test scores. 
DEMIREL \& DERETARLA GÜL- Çukurova Üniversitesi Eğitim Fakültesi Dergisi, 50(2), 2021, 721-748

Table 7.

Test for Homogeneity of Regression Slopes

\begin{tabular}{lccccc}
\hline Source & Sum of Squares & Sd & Mean Square & F & p \\
\hline Group & 41.262 & 1 & 41.262 & .529 & .474 \\
Pre-PSSS & 103.783 & 1 & 103.783 & 1.330 & .259 \\
Group X Pre-PSSS & 61.598 & 2 & 30.799 & .395 & .678 \\
Error & 2028,327 & 26 & 78.013 & & \\
Total & 55775.0 & 32 & & & \\
\hline
\end{tabular}

The final assumption required to be able to apply ANCOVA analysis is the homogeneity of regression trends. According to the results of the regression tendency test presented in Table 7, it is seen that the significance value of the interaction expression (Group X Pre-PSSS) is .678. In order to ensure the homogeneity of regression trends, this value should be greater than .05 significance value. In our finding, this value is greater than .05 significance value, therefore the assumption of homogeneity of regression trends is provided. After all the assumptions were met, ANCOVA analysis was performed to determine whether there was a significant difference between the PSSS post-test scores of the experimental and control groups when the pre-test scores of the experimental and control groups were controlled.

In the study, ANOVA test was used in Single Factor Repeated Measurements to examine whether there was a significant difference between the scores obtained from the pre-test, post-test and retention test of the experimental group. Büyüköztürk (2017) stated that ANOVA test can be used for Single-Factor Repeated Measurements only when it is desired to examine whether a time-dependent change is significant or not. Finally, the scores of the children in the experimental group obtained from the "PSSS" post-test and retention test were analyzed with the Related Samples T-Test for the groups with normal distribution. The Associated Samples T-Test is used only when there is data collected from one group in two different situations or times. Pretest and posttest or posttest and retention test situations can be given as examples of situations where this technique is used (Pallant, 2017).

\section{Findings}

In this part of the research, the data collected within the scope of the research were analyzed and presented in tables together with the sub-problems of the research.

Sub-Problem 1: Is there a significant difference between the averages of the "PSSS" post-test scores corrected according to the "PSSS" pre-test scores of the children in the experimental and control groups?

ANCOVA analysis was performed to determine whether there was a significant difference between the PSSS post-test scores of the experimental and control groups adjusted according to the PSSS pre-test scores. Findings related to the analysis are presented in Table 8.

Table 8.

Post-test Scores of Groups and Their Post-test Scores Corrected According to Pre-test Scores

\begin{tabular}{lccccccc}
\hline \multicolumn{1}{c}{ Source } & $\begin{array}{c}\text { Sum of } \\
\text { Squares }\end{array}$ & df & $\begin{array}{c}\text { Mean } \\
\text { Square }\end{array}$ & $\mathbf{F}$ & $\mathbf{p}$ & $\begin{array}{c}\text { Partial Eta } \\
\text { Squared }\end{array}$ & $\begin{array}{c}\text { Observed } \\
\text { Power }\end{array}$ \\
\hline Pre-PSSS & 539.339 & 1 & 539.339 & 7.480 & .011 & .205 & .572 \\
Group & 336.760 & 1 & 336.760 & 4.670 & .039 & .139 & .538 \\
Error & 2091.108 & 29 & 72.107 & & & & \\
Total & 2967.207 & 31 & & & & & \\
\hline
\end{tabular}

As is seen in Table 8, there was a significant difference between the corrected post-test PSSS mean scores of the experimental and control groups $(F(1-29)=4.670, p<.05$, partial eta square=.139). 
DEMIREL \& DERETARLA GÜL- Çukurova Üniversitesi Eğitim Fakültesi Dergisi, 50(2), 2021, 721-748

According to this finding, it can be said that the problem solving skill scores of the children in the experimental group were higher in the posttest than the children in the control group.

Sub-Problem 2: Is there a significant difference between the pre-test, post-test and retention scores of the children in the experimental group?

In order to determine whether the pretest-posttest-permanence tests differed in the experimental group, ANOVA was used for repeated measures with one factor. The results of the Friedman Test conducted to determine whether the scores obtained from these scales differ in the experimental group according to the pre-test, post-test and retention tests are given in Table 9.

Tablo 9.

Pre-Test, Post-Test and Retention Tests in the Experimental Group Anova Test Result

\begin{tabular}{lcccccc}
\hline Source & $\begin{array}{c}\text { Sum of } \\
\text { Squares }\end{array}$ & $\mathbf{d f}$ & $\begin{array}{c}\text { Mean } \\
\text { Square }\end{array}$ & $\mathbf{F}$ & $\mathbf{p}$ & $\mathbf{n 2}$ \\
\hline Between Groups & 2565.250 & 15 & 171.017 & & & \\
Measure & 519.292 & 2 & 259.646 & 4.421 & $.00^{*}$ & .906 \\
Error & 1765.375 & 30 & 58.846 & & & \\
Total & 4849.917 & 47 & & & & \\
\hline
\end{tabular}

$* p<.05$

According to Table 9, it was observed that there was a statistically significant difference between repeated measurements regarding the measurement scores of the children in the experimental group $(F(2,30)=4.421, p<0.05$, partial $\eta 2=.906)$. As a result of the Bonferroni comparison test performed to determine between which measurements these differences are, a significant difference was observed between the mean scores of the pre-test and post-test, pre-test and permanence test.

Sub-Problem 3: Is there a significant difference between the scores of the children in the experimental group in the "PSSS" post-test-permanence test?

In order to test whether there is a statistically significant difference between the post-test and the permanence test of the experimental group, the T-Test for Related Samples, which is one of the parametric methods, was applied and the findings are given in Table 10.

Tablo 10.

Results of Paired Sample $t$ Test of PSSS Post-Test and Retention Test Mean Scores of the Children in the Experimental Group

\begin{tabular}{|c|c|c|c|c|c|c|}
\hline Experimental Group & $\mathbf{N}$ & $\overline{\mathbf{X}}$ & SD & Std. Error & $\mathbf{t}$ & $\mathbf{p}$ \\
\hline Post-Test & 16 & 44.19 & 2.08 & 9.34 & .589 & .565 \\
\hline Retention Test & 16 & 42.81 & 2.19 & & & \\
\hline
\end{tabular}

As can be seen in Table 10, it is seen that the children in the experimental group have a mean score of 44.19 in the PSSS post-test, and a mean score of 42.81 in the permanence test. In addition, it was observed that there was no significant difference between the children's PSSS post-test and retention test mean scores $[t(9.34)=.589, p>.05)]$.

\section{Discussion \& Conclusion}

In this study, in which the effect of riddles on the problem-solving skills of 57-66 month-old children was investigated, ANCOVA test and T-Test for Related Measurements were used to analyze the collected data. It was found that the difference between the pre-test scores of the children in the experimental and control groups in the study group did not create a statistically significant difference ( $P>.05)$. When the post-test scores obtained at the end of the application were examined, it was seen that the experimental group's PSSS post-test average scores were higher than the control group's PSSS post-test scores. At the same time, the post-test scores corrected according to the pre-test scores of the groups 
were analyzed by ANCOVA analysis, and there was a significant difference between the two groups in favor of the experimental group $(p<.05)$. It can be said that this difference is due to the riddle activities applied to the experimental group, and depending on this finding, riddle activities have a positive effect on the problem solving skills of 57-66 month old children and improve the problem solving skills of the children.

In these findings obtained as a result of the research, it is thought that it is effective to base the acquisitions related to problem solving skills from the acquisitions of the cognitive development field included in the MEB 2013 Pre-School Education Program while planning the puzzle activities used. In the activities, riddles were presented to the children as a problem to be solved, and then the answer to the riddle was reached with a problem process. Hacısalihoğlu-Karadeniz (2019) stated that the riddles in the book "Saving the Queen" are also related to problem solving skills and that riddles can be used in the context of problem solving strategies.

Jirata (2012) in a study on riddles in which children between the ages of 7 and 14 asked their opinions, stated that the children stated that the riddle had educational advantages as well as being a fun race. Children stated that riddles activated their memory and helped them develop their problemsolving skills. Solesa-Grijak (2011) in a study conducted with 150 children between the ages of 4-6, expressed riddles as a type of verbal problem preferred by young children. In the study, the effect of cognitive development on solving riddles as verbal problems was examined and as a result of the research, it was concluded that as the age group increased, children were more successful in solving riddles containing simple metaphors and that language development and cognitive development were parallel.

While Tanrıkulu (2014) states that what makes the riddle really interesting for children is their desire to solve problems, Şimşek (2004) also states that riddles improve the problem-solving ability of children and accelerate their mental development, as well as teach them to come to a conclusion by solving the metaphors and symbols in it and making use of the clues. In this research, it was ensured that the riddles used in planning riddle activities were found by going through a problem solving process together with a planning that might attract the attention of children. In the activities, clues were prepared about what the riddle was in that day, and it was supported that the children could reach the answer of the riddle by solving the metaphors in the riddle.

In his study, Çobanoğlu (2017) examined the effect of using riddles in the teaching of some subjects included in the primary school second grade mathematics course on student achievement, attitudes towards mathematics and the permanence of knowledge. As a result of the study, he stated that riddles had a positive effect on the success of primary school students, their attitudes towards mathematics and the permanence of knowledge. Similarly, in this study, a significant difference between the pre-test and post-test scores of the experimental group and the pre-test and retention test showed that riddles had an effect on problem-solving skills and this effect continued during this time $(p<.05)$. In the light of the findings obtained from the research, in reaching the finding that riddle activities are effective on children's problem solving skills; In the process of reaching the answer to the riddle, the children were also provided with a problem-solving process. In this process, children have gone through different thinking and reasoning processes while reaching the answers to different riddles presented to them.

Riddles, one of the activities included within the scope of language activities in the MEB 2013 PreSchool Education Program, were included in this study as an integrated activity, basically as language activities. Birgül and Akyol (2018) concluded that the activities included within the scope of Turkish activities support 60-69-month-old children to look for different solutions and improve their problemsolving skills. The findings obtained as a result of this research support this idea. below.

Based on the results of the research, suggestions for practice and future research are presented

\section{Implementation Recommendations}


DEMIREL \& DERETARLA GÜL- Çukurova Üniversitesi Eğitim Fakültesi Dergisi, 50(2), 2021, 721-748

1. As a result of the research, it was seen that riddle activities were effective on problem solving skills. In this context, it should be supported to include riddles in activities in order to develop children's problem-solving skills in the preschool education process.

2. One of the data obtained as a result of the research was that some parents did not ask their children riddles. In this context, it is possible to plan activities that include riddles as a family participation activity by teachers.

3. As a result of the research, the teachers stated that they asked riddles as a pre-story transition activity or about the topic they included that day. In this context, an activity book containing riddle activities on different topics can be prepared by researchers for teachers.

\section{Suggestions for Future Research}

1. In the study, 57-66 months old children were studied. Studies to be carried out can be carried out with children in other age groups.

2. The implementation process in the study was carried out only with children aged 57-66 months. In future studies, parents and teachers can be actively involved in the implementation process.

3. In the study, only the effect of riddles on problem solving skills was examined. In future studies, the effects of riddles on language development and creative thinking skills can be examined along with problem solving skills.

4. With this experimentally planned study, the problem solving skills of children in the process were evaluated only based on the results of the scale. In future studies, how children's problem-solving skills develop during the process can be examined by researchers through classroom observations and interviews with teachers and parents.

\section{Ethical Consent of the Research}

In this study, all the rules specified to be followed within the scope of "Higher Education Institutions Scientific Research and Publication Ethics Directive" were complied with. None of the actions specified under the title of "Actions Contrary to Scientific Research and Publication Ethics", which is the second part of the directive, have been taken. 
Okul öncesi dönem diğer yaşam dönemlerine göre farklı gelişim alanlarının birbirlerinden en fazla etkilendiği ve çocuğun oldukça hızlı geliştiği bir dönem olduğundan çocuklara bu dönemde verilecek eğitimin ihtiyaçlarına uygun olarak gelişimini desteklemesi gerekmektedir (Kandır ve Alpan, 2008; MEB, 2013; Oktay, 2007). Okul öncesi eğitim sürecinde öğretmen, etkinlikler aracılığıyla çocuğa, nitelikli bilişsel uyarıcılar ve zengin dil etkileşimleri sunar, çocuğun kendi yeteneklerini keşfetmesine yardımcı olur (Katrancı, 2018; MEB, 2013). Bu etkinlik çeşitlerinden biri de Türkçe etkinlikleridir (MEB, 2013). Türkçe etkinlikleri, çocukların Türkçeyi doğru ve güzel konuşmalarını, sözcük dağarcıklarını geliştirmeyi ve iletişim becerilerini artırmayı planlayan etkinliklerdir. Türkçe etkinlikleri planlanırken okul öncesi öğretmenleri tarafından farklı yöntem ve teknikler kullanılmalı ayrıca çocukların içinde bulundukları gelişim dönemi dikkate alınarak eğitim ortamı buna göre düzenlenmelidir (MEB, 2013).

Okul öncesi eğitim sürecinde yer verilen Türkçe etkinliklerinden biri olan ve çocukların keyifle katıldıkları bilmece etkinlikleri çocukların dil gelişimlerini ve sözcük dağarcıklarını destekleyen öğretim araçlarından biridir (Alan, 2019; Balta, 2013). Bir öğretim aracı olarak bilmeceler; kavramların zihinde somutlaştırılmasında, benzerlikleri ve farklılıkları ortaya koymada, cevabı bulmada tümevarım yollarının izlenmesinde ve soru cevap stratejisinde kullanılabilmektedir (Balta, 2013). Cevabı gizlenmiş veya dolaylı olarak sunulmuş bilmecelerin en belirgin özelliği kafa karışıklığı yaratmasıdır. Gizlenmiş olanı bulma sürecinde alışılmamış benzetmeler kullanılması, hızlı düşünme ve alışıldık düşünme yollarını alt üst ederek çocuğun bilişsel düşünme becerilerini geliştirmektedir (Abrahams ve Dundes, 2007'den akt. Balta, 2013; Stefanova, 2007).

Alan yazın incelendiğinde bilmeceler ve bilmecelerin önemi ile ilgili çalışmaların yer aldığı görülmüştür. Bu çalışmalar, bilmecelerin anlama becerisi (Belanger, Kirkpatrick ve Derks, 1998; Binsted, Pain ve Ritche, 1997; Dowling, 2014; Ely ve Mccabe, 1994; Ezell ve Jarzynka, 1996; Firestien ve Mccowan, 1988; Goldstein, Harman, Mcghee, Karasik, 1975; Guo, Zhang, Wang ve Xeromeritou, 2011; Korovkin ve Nikiforova, 2015; Mai, Luo, Wu ve Luo, 2004; Pepicello, 1989; Smullyan, 1978; Stefanova, 2007; Sutton-Smith, 1973; Van Dooren, Lem, De Wortelaer ve Verschaffel, 2019; Waithaka, 2017; Whitt ve Prentice, 1977), dil öğrenimi (Erkan, 2015; Lee, 2019; Mert, 2012; Özkara, 2013; Yılmaz ve Taşkın, 2014), dil gelişimi (Ruiz Gurillo, 2017; Taner Derman, Ergişi Birgül ve Şahin Zeteroğlu, 2019), kelime öğretimi (Erdoğan, Altınkaynak ve Erdoğan, 2013; Karayazı ve Karakuş, 2018; Oruç, 2011), çocuklara anadil sevgisini kazandırma (Yangil ve Kerimoğlu, 2014), bilişsel gelişim (Baker, 2017; Birgül ve Akyol, 2018; Çobanoğlu, 2017; Ersoy, 1986; Guo, Zhang, Whang, Xeromeritou, 2011; Montalvo-Castro, 2011; Motroni, 2016; Taşkın ve Tuğrul, 2014) ve kavram gelişimi (Hayran, 2010) üzerinde etkili olduğu aynı zamanda bilmecelerin öğretim aracı olarak (Keleş, 2007) kullanılabileceği ifade edilmiştir. İlgili çalışmalar incelendiğinde okul öncesi eğitim sürecinde bilmecelerin kullanımı ile ilgili araştırmaların çoğunlukla yurtdışı kaynaklı olduğu görülmüştür. Yurtiçi çalışmalarda, okul öncesi eğitimde bilmecelerin önemi ifade edilmesine rağmen bilmecelerle ilgili çalışmaların kısıtlı olduğu görülmüştür.

Gönen vd (2010), tarafından yapılan çalışmada okul öncesi öğretmenlerinin bilmecelere, dil etkinliklerine hazırlık aşamasında veya hikâye ile ilgili bilmece sorma olarak yer verdikleri görülmüştür. Araştırmada bilmecelerin öğretmenler tarafından en az yer verilen etkinliklerden biri olduğu ifade edilmiştir. Bunun sebebinin öğretmenlerin bilmeceleri çoğunlukla başka bir dil etkinliğine hazırlık aşamasında sunmalarından dolayı yapılacak çalışmaya uygun bilmece bulmakta zorluk yaşamalarından kaynaklı olduğu düşünülmüştür. Tepetaş-Cengiz vd (2018) tarafından okul öncesi öğretmenlerinin planlarında yer verdikleri Türkçe etkinlikleri ve bu etkinliklere yönelik görüşlerinin incelendiği çalışmada öğretmenler bilmecelere, Türkçe etkinliklerinden önce dikkat çekme ve ısınma amacıyla haftada iki üç kez yer verdiklerini ifade etmişlerdir. 
Bilmecelerle ilgili yapılmış çalışmalar incelendiğinde, bilmecelere okul öncesi eğitimi kapsamında Türkçe etkinliği dışında başka etkinliklerde de yer verildiği görülmüştür. Altun ve Tantekin-Erden (2016), okul öncesi öğretmenliği bölümünde okuyan öğrenciler ile yaptıkları çalışmada öğrencilerin erken okuryazarık ile ilgili görüşlerini incelemeyi amaçlamışlardır. Çalışma sonucunda elde ettikleri bulgularda, öğretmen adaylarının bilmecelere erken okuryazarlığı destekleyici etkinlik olarak yer verdikleri görülmüştür. Tuğrul vd (2014), altı yaşındaki çocukların ve öğretmenlerinin oyun etkinlikleri hakkındaki görüşlerini inceledikleri çalışmalarında öğretmenlerin oyun etkinliği olarak bilmecelere yer verdiklerini ifade etmişlerdir. Erdoğan vd 2013), okul öncesi eğitimi öğretmenlerinin okuma ve yazmaya hazırlık etkinliklerini incelediklerinde öğretmenlerin, bilmecelere ayrı bir etkinlik olarak yer vermedikleri, geçiş etkinlikleri sırasında yer verdiklerini ifade etmişlerdir. Alan yazında bilmece ile ilgili olarak daha çok öğretmen veya öğretmen adaylarının görüşlerinin alındığı çalışmalara nazaran Ergişi (2014), Türkçe etkinliklerinin okul öncesi dönem çocuklarının gelişimlerine etkisini incelemeyi amaçladığı çalışmasında bilmecelere, çocuklara bilmece sorma, cevabını ipuçlarıyla buldurma veya çocuklarla bilmece oluşturma olarak yer vermiştir.

Okul öncesi dönemde bilmecelerin bilişsel gelişimle ilişkisinden yola çıkacak olursak, çocukları düşünmeye yönlendirmesi ve bilmece içinde geçen kavramın en çarpıcı noktalarına vurgu yaparak çocukların bu noktalara daha dikkatli bir bakmalarını desteklemesiyle aslında bir çeşit biliş jimnastiği olarak düşünebiliriz (Çelebioğlu ve Öksün, 1995; akt. Kabadayı, 2007). Ayrıca bilmeceler bilişsel alan basamaklarının tüm aşamalarını da içerebilmesi bakımından bilişsel gelişim açısından da oldukça önemlidir (Kabadayı, 2007). Guo vd. (2011) bir çalışmalarında mizah etkinlikleri kapsamında bilmecelere de yer vermiş ve mizah etkinliklerinin bilişsel gelişimle yakından ilişkili olduğunu ifade etmişlerdir. Bilişsel gelişimle bağlantılı olan bilmeceler, analiz etme, kavramlar ve olaylar arasında bağlantı kurma, neden sonuç ilişkisi oluşturma ile çağrışımsal ve yaratıcı düşünmeyi geliştirerek doğrudan problem çözme becerisi ile de ilişkili olmaktadır (Altunbay, 2014; Sarıca, Aksu ve Yurdakul, 2012).

Ely ve McCabe (1994) yaptığı bir çalışmasında, anaokulu çocuklarının yaklaşık dörtte birinin günlük ifadelerinin bilmeceler ve diğer mizah türleri dahil olmak üzere bir tür dil oyununu içerdiğini ifade etmiştir. Daha önce ifade edildiği gibi bir soru-cevap yöntemi ve aynı zamanda dil oyunu olan bilmeceler, özellikle 5-6 yaş dönemi çocuklar için çözebilecekleri problemler olarak düşünülebilir (Doolittle, 1995; Guo, Zhang, Whang ve Xeromeritou, 2011). Pepicello (1989), yapmış olduğu bir çalışmada bilmeceleri, yanıtlayıcı tarafından bir sorunun çözülmesinin amaçlandığı bir nevi 'dilbilimsel problemler' olarak tanımlamıştır. Bu çalışmada vurgulanan şey, bireyin bilmeceyi çözmedeki başarısı, belirsizlik içeren bir dil problemini özel olarak akılda tutma ve bu problemi benzersiz bir çözüm ile çözebilme becerisine bağlıdır.

Okul öncesi eğitimde bilmecelere yer vermenin problem çözme becerisi üzerinde etkili olduğu alanyazında desteklenirken (Balta, 2013; Kllıçarslan, 2015; MEGEP, 2016); bilmece ve problem çözme becerisi iliş̧isi üzerinde yapılmış araştırmaların da çoğunlukla yurtdışı kaynakı olduğu (Belanger, Kirkpatrick ve Derls, 1998; Dewi ve Bektiarso, 2017; Doolittle, 1995; Firestien ve Mccowan, 1988; Goldstein, Harman, Mcghee ve Karasik, 1975; Guo, Zhang, Wang ve Xeromeritou, 2011; Himah, Bektiarso ve Prihandono, 2015; Korovkin ve Nikiforoya, 2015; Masfuah, 2016; Smullyan, 1978; Van Dooren, Lem, Lem, S., De Wortelaer ve Verschaffel, 2019; Waithaka, 2017; Yuill, 2009), yurtiçinde yapılmış çalışmaların ağırlıkıı olarak ilkokul düzeyinde (Karadeniz, 2018) yapıldığı görülmüştür.

Tüm bunlardan hareketle; 'Bilmeceler, 57-66 aylık çocukların problem çözme becerisi üzerinde etkili midir?' sorusu araştırmanın problemi olarak belirlenmiştir.

Araştırmanın genel problemi doğrultusunda aşağıdaki alt problemlere yanıt aranmıştır:

1. Deney ve kontrol grubunu oluşturan çocukların "РÇBÖ" ön test puanlarına göre düzeltilmiş "РС̧ВÖ" son test puanlarının ortalamaları arasında anlamlı düzeyde fark var mıdır?

2. Deney grubundaki çocukların "РÇBÖ" ön test, son test ve kalıılık puanları arasında anlamlı düzeyde farklııı var mıdır? 
DEMIREL \& DERETARLA GÜL- Çukurova Üniversitesi Eğitim Fakültesi Dergisi, 50(2), 2021, 721-748

3. Deney grubundaki çocukların "РÇBÖ" son test-kalıcılık testi puanları arasında anlamlı düzeyde fark var mıdır?

\section{Yöntem}

\section{Araştırma Modeli}

Bilmece etkinliklerinin 57-66 aylık çocukların problem çözme becerisine etkisini incelemeyi amaçlayan bu araştırmanın modeli, zayıf deneysel desenlerden biri olan ön test-son test denkleştirilmemiş gruplu desendir. Bu desende araştırma grubundan uygulama öncesinde bağımlı değişkene Problem Çözme Becerisi Ölçeği (РÇВÖ)'nden elde edilen puanlar) ait ölçümleri elde edilir. "Seçkisiz atamanın mümkün olmadığı bu desende hazır gruplar kullanılmakta ve bu desen grupların (deney-kontrol) ölçülen değişkenle ilgili başlangıç noktalarının bilinmesine, böylece değişimin ölçülmesi olanak tanır" (Büyüköztürk, Kılıç-Çakmak, Akgün, Karadeniz ve Demirel, 2012). Bu araştırmada bilmece etkinlikleri araştırmanın bağımsız değişkenini, 57-66 aylık çocuklara uygulanan PÇBÖ’den elde edilen puanlar ise araştırmanın bağımlı değişkenini oluşturmaktadır.

Tablo 4.

Araştırma Deseni

\begin{tabular}{ccccc}
\hline Grup & Ön Test & işlem & Son Test & Kalıcılık Testi \\
\hline GD & $\mathrm{O}_{1}$ & Bilmece Etkinlikleri & $\mathrm{O}_{3}$ & $\mathrm{O}_{5}$ \\
& & + \\
& & & \\
& & MEB (2013) Eğitim \\
Programı & \\
GK & $\mathrm{O}_{2}$ & MEB (2013) Eğitim \\
& & Programı & $\mathrm{O}_{4}$ \\
\hline
\end{tabular}

GD; Bilmece etkinliklerinin uygulandığı deney grubunu,

GK; Kontrol grubunu,

$\mathrm{O}_{1}-\mathrm{O}_{3}-\mathrm{O}_{5}$; Deney grubuna uygulanan ön test- son test- kalıcılık testi ölçümlerini,

$\mathrm{O}_{2}-\mathrm{O}_{4}$; Kontrol grubuna uygulanan ön test- son test ölçümlerini ifade etmektedir.

\section{Araştırmanın Çalışma Grubu}

Araştırmanın çalışma grubu, 2020-2021 Eğitim-Öğretim yılında Muş ilinde MEB’e bağlı iki farklı özel okul bünyesindeki iki anasınıfında öğrenim gören 32 çocuktan oluşmaktadır. Deney grubunda 16, kontrol grubunda 16 çocuk bulunmaktadır. Deney ve kontrol grubundaki çocukların dil-bilişsel gelişimlerinin normal gelişim gösterip göstermediklerini belirlemek amacıyla Ankara Gelişim Tarama Envanterinin (AGTE) Dil-Bilişsel Gelişim bölümü kullanılmıştır. Envanterden alınan puanların sonucuna göre her iki gruptaki çocukların dil-bilişsel gelişim düzeylerinin normal düzeyde olduğu görülmüştür.

Çalışma grubunu oluşturan okulların belirlenmesinde grupların birbirleri ile etkileşim içerisinde olmaması, daha önce benzer bir çalışmaya katılmamış olmaları, grupların sosyoekonomik durum, yaş ve dil gelişim özellikleri dikkate alınmıştır. Tablo 2'de çalışma grubuna ilişkin bilgiler sunulmuştur. 
DEMIREL \& DERETARLA GÜL- Çukurova Üniversitesi Eğitim Fakültesi Dergisi, 50(2), 2021, 721-748

Tablo 5.

Çalışma Grubuna iliş̧kin Demografik Bilgiler

Çocukların Cinsiyet Dağılımı

\begin{tabular}{|c|c|c|c|}
\hline Grup & Cinsiyet & $f$ & $\%$ \\
\hline \multirow[t]{3}{*}{ Deney } & Kız & 9 & 56.25 \\
\hline & Erkek & 7 & 43.75 \\
\hline & Toplam & 16 & 100.0 \\
\hline \multirow[t]{3}{*}{ Kontrol } & $\mathrm{K} ı \mathrm{z}$ & 11 & 68.75 \\
\hline & Erkek & 5 & 31.25 \\
\hline & Toplam & 16 & 100.0 \\
\hline \multicolumn{4}{|c|}{ Çocukların Ay Ortalamalarına Göre Dağılımları } \\
\hline Grup & Ay Ortalaması & $f$ & Ortalama \\
\hline Deney & $56-66$ & 16 & 100.0 \\
\hline Kontrol & $56-66$ & 16 & 100.0 \\
\hline \multicolumn{4}{|c|}{ Çocukların Kardeş Dağılımları } \\
\hline Grup & Kardeş Sayısı & $f$ & $\%$ \\
\hline \multirow[t]{4}{*}{ Deney } & .00 & 8 & 50.0 \\
\hline & 1.00 & 7 & 43.75 \\
\hline & 2.00 & 1 & 6.25 \\
\hline & Toplam & 16 & 100.0 \\
\hline \multirow[t]{6}{*}{ Kontrol } & .00 & 5 & 31.25 \\
\hline & 1.00 & 4 & 25.0 \\
\hline & 2.00 & 2 & 12.5 \\
\hline & 3.00 & 3 & 18.75 \\
\hline & 4.00 & 2 & 12.5 \\
\hline & Toplam & 16 & 100.0 \\
\hline \multicolumn{4}{|c|}{ Çocukların Anne Eğitim Durumları } \\
\hline Grup & Anne Eğitim Durumu & $f$ & $\%$ \\
\hline \multirow[t]{3}{*}{ Deney } & Lise & 4 & 25.0 \\
\hline & Üniversite & 12 & 75.0 \\
\hline & Toplam & 16 & 100.0 \\
\hline \multirow[t]{4}{*}{ Kontrol } & Ortaokul & 1 & 6.0 \\
\hline & Lise & 6 & 38.0 \\
\hline & Üniversite & 9 & 56.0 \\
\hline & Toplam & 16 & 100.0 \\
\hline \multicolumn{4}{|c|}{ Çocukların Baba Eğitim Durumları } \\
\hline Grup & Baba Eğitim Durumu & $f$ & $\%$ \\
\hline \multirow[t]{3}{*}{ Deney } & Lise & 2 & 13.0 \\
\hline & Üniversite & 14 & 87.0 \\
\hline & Toplam & 16 & 100.0 \\
\hline \multirow[t]{3}{*}{ Kontrol } & Lise & 4 & 25.0 \\
\hline & Üniversite & 12 & 75.0 \\
\hline & Toplam & 16 & 100.0 \\
\hline
\end{tabular}

Tablo 2 incelendiğinde; deney grubunda 9 kız (\%56.25), 7 erkek (\%43.75), kontrol grubunda 11 kız (\%68.75), 85 erkek (\%31.25) çocuğun olduğu görülmektedir. Deney grubunu oluşturan çocuklardan tek çocuk olan 8 (\%50.0), tek kardeşi olan 7 (\%43.75), iki kardeşi olan 1 (\%6.25) çocuk olduğu görülmektedir. Kontrol grubundaki çocuklardan ise tek çocuk olan 5 (\%31.25), bir kardeşi olan 4 (\%25.0), iki kardeşi olan 2 (\%12.5), üç kardeşi olan 3 (\%18.75) ve dört kardeşi olan 2 (\%12.5) çocuk olduğu görülmektedir. Deney grubundaki çocukların anne eğitim durumlarına bakıldığında 4 (\%25.0) kişinin lise ve 12 (\%75.0) kişinin 
ise üniversite olduğu görülmektedir. Kontrol grubundaki çocukların anne eğitim durumları ise 1 (\%6.0) kişi ortaokul, 6 (\%38.0) kişi lise ve 9 (\%56.0) kişinin üniversite olduğu görülmektedir. Deney grubundaki çocukların baba eğitim durumlarına bakıldığında 2 (\%13.0) kişinin lise ve 14 (\%87.0) kişinin ise üniversite olduğu görülmektedir. Kontrol grubundaki çocukların baba eğitim durumlarına bakıldığında 4 (25.0) kişinin lise ve 12 (\%75.0) kişinin üniversite olduğu görülmektedir.

Tablo 6.

Çocukların Öğretmenlerine iliş̧in Demografik Bilgiler

\begin{tabular}{ccccc}
\hline Grup & Cinsiyet & Öğrenim Düzeyi & $\begin{array}{c}\text { Lisans Mezuniyet } \\
\text { Alanı }\end{array}$ & $\begin{array}{c}\text { Mesleki Kıdem } \\
\text { Yılı }\end{array}$ \\
\hline Deney & Kadın & Lisans & Okul Öncesi Eğitimi & 3 \\
\hline Kontrol & Kadın & Lisans & Okul Öncesi Eğitimi & 5 \\
\hline
\end{tabular}

Tablo 3 incelendiğinde deney ve kontrol grubundaki çocukların öğretmenlerinin cinsiyetinin kadın olduğu ve öğrenim düzeylerinin lisans olduğu görülmektedir. Deney grubu öğretmeninin lisans mezuniyet alanının okul öncesi eğitimi olduğu, kontrol grubu öğretmeninin ise çocuk gelişimi mezunu olduğu görülmektedir. Ayrıca deney grubu öğretmeninin mesleki kıdem yııının 3 yıl, kontrol grubu öğretmeninin ise 5 yıl olduğu görülmektedir.

\section{Veri toplama araçları}

Araştırmada deney ve kontrol grubunu oluşturan çocuklara ve ailelerine dair bilgi almak için araştırmacı tarafından geliştirilen Genel Bilgi Formu kullanılmışı. Deney ve kontrol grubunu oluşturan çocukların okul öncesi eğitimi öğretmenleri için ise yine araştırmacı tarafından hazırlanan Öğretmen Bilgi Formu kullanılmıştır. Deney grubuna ön test, son test ve kalıclık testi olarak; kontrol grubuna ise ön test ve son test olarak Oğuz ve Köksal-Akyol (2015)'un geliştirdiği "Problem Çözme Becerisi Ölçeği (PÇBÖ)" araştırmacı tarafından uygulanmıştır.

\section{Genel Bilgi Formu}

Deney ve kontrol grubunu oluşturan çocukların kendileri ve ailelerine ilişkin bilgi almak için ön test uygulanmadan önce, araştırmacılar tarafından hazırlanan Genel Bilgi Formu ebeveynlere uygulanmıştır. Genel bilgi formunda, deney ve kontrol grubuna dahil edilen çocukların doğum tarihleri, cinsiyetleri ve kardeş sayılarına yönelik sorulara yer verilmiştir. Formda çocukların ebeveynlerine yönelik olarak da anne-baba öğrenim durumuna yönelik sorulara yer verilmiştir.

\section{Öğretmen Bilgi Formu}

Öğretmen Bilgi Formu, deney ve kontrol grubunu oluşturan çocukların okul öncesi eğitimi öğretmenlerine uygulanmıştır. Araştırmacı tarafından hazırlanan formda deney ve kontrol grubundaki çocukların öğretmenlerinin cinsiyeti, öğrenim durumları, lisans mezuniyet alanları ve mesleki kıdem yıllarına yönelik sorulara yer verilmiştir. Form öğretmenlere ön test uygulanmadan önce araştırmacı tarafından uygulanmıştır.

\section{Problem Çözme Becerisi Ölçeği (PÇBÖ)}

Araştırmada deney ve kontrol grubundaki çocukların, problem çözme becerisi puanlarını belirlemek için Oğuz ve Köksal-Akyol (2015)'un geliştirdiği "Problem Çözme Becerisi Ölçeği (PÇBÖ)" kullanılmıştır. Ölçekte 18 farklı problem durumu ve bu problem durumuna ilişkin çizimler bulunmaktadır. Beşli likert tipi ölçek olarak hazırlanan “РÇBÖ’de her bir problem durumuna üretilen çözüm için 0-4 arası puanlar alınmaktadır. PÇBÖ’den alınacak puan aralığı 0-72'dir. Oğuz ve Köksal-Akyol (2015)'e göre PÇBÖ’de önemli olan çocuğun daha çok alternatif çözüm üretebilmesidir ve sorular birer araçtır. Çocuğun verdiği cevapların hangi sorulardan geldiği önemli değildir, amaç cevap sayısıdır. 
DEMIREL \& DERETARLA GÜL- Çukurova Üniversitesi Eğitim Fakültesi Dergisi, 50(2), 2021, 721-748

Oğuz ve Köksal-Akyol (2015) geliştirdikleri "Problem Çözme Becerisi Ölçeğinin" geçerliliği kapsam geçerlik indeksi (KGi) ve açımlayıcı faktör analizi (AFA) uygulanarak belirlenmiştir. Maddelerin uygunluk düzeyi için KGI .99; maddelerin çizimlere uygunluk düzeyi için ise KGi .96 olarak hesaplamıştır. "Bu değerler ölçekteki tüm maddelerin gerekli olduğunu ve ölçeğin bir bütün olarak kapsam geçerliğini sağladığı anlamına gelmektedir" (Oğuz ve Köksal-Akyol, 2015). PÇBÖ’ye yapılan AFA sonucunda ölçeğin tek faktörlü olduğu sonucuna varılmıştır. Bu faktör, ölçeğe ilişkin toplam varyansın \%30.68'ini açıklamaktadır. Tek faktörlü ölçeklerde varyansın \%30 ve daha fazla olması yeterli olmaktadır (Büyüköztürk, 2010). Ayrıca, ölçeğin güvenirlik çalışması için Cronbach Alfa iç tutarlılık anlamında güvenirlik katsayısı ve Test Tekrar Test Kararlılık anlamında güvenirlik katsayısı hesaplanmış ve bu değer .86 olarak bulunmuştur. Likert tipi bir ölçek için bu ölçeğin güvenirliğinin yüksek düzeyde olduğu söylenebilir (Tezbaşaran, 1997'den akt. Oğuz ve Köksal-Akyol, 2015).

\section{Veri toplama süreci}

Muş ilinde bulunan ve MEB'e bağı olan iki özel anasınıfında gerçekleştirilen araştırmanın asıl uygulama süreci öncesinde gerekli olan araştırma izinleri alınmıştır. 2019-2020 Eğitim Öğretim yılı ŞubatMart aylarında çalışmanın pilot uygulaması gerçekleştirilmiştir. Pilot uygulama sürecinde 12 etkinlik uygulanmış ve bu etkinlik planlarında yer verilen bilmecelerde geçen kavramlara çocukların aşinalığı, bilmeceyi çözme süreci ve süreç sonunda etkinlik planlarında yer verilen kazanım göstergelere ulaşılma durumu gözlenmiştir. Pilot uygulama süreci sonunda bazı bilmecelerin çocukların bilmedikleri kavramlara ait olduğu görülmüş ve bu nedenle bazı bilmece etkinlikleri değiştirilmiştir. Bilmeceyi çözme sürecinde yer verilen sorular ve etkinlikler çeşitlendirilmiş, planda yer alan kazanım ve göstergelere ulaşllacak biçimde düzenlenmiştir.

Araştırmanın deney grubuna sekiz hafta boyunca haftada iki gün toplam 16 bilmece etkinliği uygulanmıştır. 16 etkinlik planı hazırlanırken MEB tarafından hazırlanan 2013 Okul Öncesi Eğitim Programında yer verilen kazanım ve göstergeler dikkate alınmıştır. Çocuklara sorulacak bilmeceler seçilirken, bilmecelerin somut kavramlara ait olmalarına dikkat edilmiştir. Etkinlikler planlanırken çocukların bilmecelerin cevabına bir problem çözme sürecinden geçerek ulaşmaları sağlanmıştır. Etkinliklerde o günün etkinlik planında yer alan bilmece ne ise onunla alakalı olarak ipuçları, resim kartları ve yapbozlar hazırlanıp çocukların bilmecenin cevabına ulaşabilmeleri desteklenmiştir. Etkinlik planları için önce uzman görüşü alınmış, uzman görüşü doğrultusunda yeniden düzenlenmiştir. Asıl uygulama öncesi pilot uygulama gerçekleştirilmiş, uygulama sonrası gerekli düzenlemeler yapılmış, tekrar uzman görüşüne sunulup son hali verilmiştir. Yaklaşık olarak 20-35 dakika süren etkinlikler araştırmacı tarafından uygulanmış; video kaydına izin verilmediği için yalnızca fotoğraf çekilmiş ve etkinlik süreci ses kaydına alınmıştır. Her etkinlik sonunda çocukların etkinlik sürecine ilişkin görüşlerini ifade etmeleri için değerlendirme soruları yöneltilmiştir.

\section{Etik kurul izin bilgileri}

Etik değerlendirmeyi yapan kurul adı: Çukurova Üniversitesi, Sosyal Bilimler Enstitüsü Etik Kurulu

Etik değerlendirme kararının tarihi: 28.01.2020

Etik değerlendirme belgesi sayı numarası: 75137396-199

\section{Verilerin analizi}

Araştırma sürecinde toplanan veriler SPSS 26.0 programı kullanılarak analiz edilmiştir. Deney ve kontrol grubundaki çocukların PÇBÖ (ön test-son test- kalıcılık testi)'den aldıkları puanların normal dağılımları örneklem sayısı 50'den küçük olduğu için Shapiro-Wilk Testi ile incelenmiştir (Büyüköztürk, 2010). Gruplara ait verilerin aritmetik ortalaması (X), minimum (Min), basıklık katsayısı (BK), standart sapması (SS), maksimum (Mak) değerleri çarpıklık katsayısı (ÇK) ve dağılımın normal olup olmadığını tespit etmek için Shapiro-Wilk Testi uygulanmıştır. Yapılan analizlere ilişkin sonuçlar Tablo 4-5-6'da gösterilmiştir. 
DEMIREL \& DERETARLA GÜL- Çukurova Üniversitesi Eğitim Fakültesi Dergisi, 50(2), 2021, 721-748

Tablo 4.

Deney ve Kontrol Grubu PÇBÖ Ön Test Ölçümlerine Ilişkin Betimsel Istatistik Değerleri ve Normallik Testi Sonuçları

\begin{tabular}{lcccccccc}
\hline Grup & $\mathbf{N}$ & $\overline{\mathbf{X}}$ & Ss & Min & Mak & ÇK & BK & Shapiro-Wilk Testi \\
\hline Deney & 16 & 36.63 & 11.95 & 23.00 & 62.00 & .960 & .186 & .073 \\
Kontrol & 16 & 34.63 & 11.87 & 22.00 & 63.00 & 1.050 & .875 & .053 \\
\hline
\end{tabular}

Tablo 4 incelendiğinde РС̧ВÖ ön test uygulamasından grupların aldıkları ön test puan ortalamalarının deney grubunda 36.63 , kontrol grubunda ise 34.63 olduğu görülmektedir. Buradan hareketle PÇBÖ ön test ölçümlerinin deney ve kontrol grubu için birbirine yakın değerde olduğu söylenebilir Deney grubunda ölçekten alınan en küçük değer 23.00 en büyük değer 62.00 iken kontrol grubunda ölçekten alınan en küçük değer 22.00 en büyük değer ise 63.00 olduğu görülmektedir. Grupların çarpıklık (ÇK) ve basıklık (BK) değerleri incelendiğinde değerlerin, standart değer olan -1.96 ile +1.96 arasında olduğu ve puanların normal dağılım gösterdikleri söylenebilir (Field, 2009). Ayrıca deney ve kontrol grubuna ait РÇBÖ ön test Shapiro-Wilk Test sonuçları da dağılımın normal olduğunu göstermektedir ( $p>.05)$.

Tablo 5.

Deney ve Kontrol Grubu PÇBÖ Son Test Ölçümlerine Iliş̧kin Betimsel İstatistik Değerleri ve Normallik Testi Sonuçları

\begin{tabular}{lcccccccc}
\hline Grup & $\mathbf{N}$ & $\overline{\mathbf{X}}$ & Ss & Min & Mak & ÇK & BK & Shapiro-Wilk Testi \\
\hline Deney & 16 & 44.19 & 8.30 & 33.00 & 61.00 & .760 & .092 & .287 \\
Kontrol & 16 & 37.00 & 10.32 & 20.00 & 56.00 & .031 & -.365 & .877 \\
\hline
\end{tabular}

Tablo 5 incelendiğinde РÇBÖ son test ölçümlerinden grupların aldıkları son test puan ortalamalarının deney grubunda 44.19 kontrol grubunda ise 37.00 olduğu görülmektedir. Deney grubunda ölçekten alınan en küçük değer 33.00 en büyük değer 61.00 iken kontrol grubunda ölçekten alınan en küçük değer 20.00 en büyük değer ise 56.00 olduğu görülmektedir. Grupların çarpıklık (ÇK) ve basıklık (BK) değerleri incelendiğinde değerlerin, standart değer olan -1.96 ile +1.96 arasında olduğu ve puanların normal dağılım gösterdikleri söylenebilir (Field, 2009). Ayrıca deney ve kontrol grubuna ait PÇBÖ son test Shapiro-Wilk Testi sonuçları da dağılımın normal olduğunu göstermektedir ( $p>.05)$.

Tablo 6.

Deney Grubu PÇBÖ Kalıcılık Testi Ölçümlerine Ilişkin Betimsel Istatistik Değerleri ve Normallik Testi Sonuçları

\begin{tabular}{ccccccccc}
\hline Grup & $\mathbf{N}$ & $\overline{\mathbf{X}}$ & Ss & Min & Mak & Ç.K. & B.K. & Shapiro-wilk Test \\
\hline Deney & 16 & 42.8125 & 8.76522 & 26.00 & 61.00 & .422 & .486 & .541 \\
\hline
\end{tabular}

Tablo 6 incelendiğinde çarpıklık (.422) ve basıklık (.486) değerlerinin \%5 anlamlılık düzeyinde ve standart değer olan -1.96 ve +1.96 değerleri arasında olduğu ve puanların normal dağılım gösterdikleri görülmektedir (Field, 2009). Tablo 15'te yer verilen Shapiro-Wilk Testinden elde edilen değerde kalıcılık testinden elde edilen değerlerin normal dağılım gösterdiğini belirtmektedir ( $p>0.05)$. Deney grubunun son test ve kalıcılık testi puanlarının normal dağılım gösterdiği tespit edilmiştir.

Araştırmanın alt problemlerinin sınanması için ANCOVA, Tek Faktörlü Tekrarlanan Ölçümlerde ANOVA, Tek Faktörlü ve İlişkili Örneklemler için T Testi kullanılmıştır. Her iki grubun ön test puanları kontrol altına alındığında son test puanlarının hesaplanmasında ANCOVA analizi kullanılmıştır. ANCOVA analizi yapılmadan önce deney ve kontrol grupları için dağılım normalliği, regresyon eğilimi eşitliği ve gruplar arasında varyansların homojenliği varsayımları test edilmiş olup elde edilen sonuçlar bu varsayımlar sağlandığı için ANCOVA analizi kullanılmıştır. ANCOVA analizi için öncelikle analizin yapılabilmesi için gerekli olan varsayımlar kontrol edilmiştir (Pallant, 2017). Varsayımlardan biri kovaryetlerin uygulama öncesinde ölçülmesini ifade etmektedir. Deney ve kontrol gruplarına uygulanan РÇBÖ uygulama öncesinde uygulandığından bu varsayım sağlanmaktadır. Bir diğer varsayım kovaryetlerin güvenirliğidir. En az .70 olması gereken Cronbach alfa değeri, PÇBÖ için .86 olduğundan bu varsayım sağlanmıştır. 
Bir diğer varsayım ise tüm gruplar için bağımlı değişken ile kovaryet arasında doğrusal bir ilişki olduğu varsayımıdır. Gruplara ait ön test ve son test PÇBÖ puanları arasındaki ilişkilerin doğrusallığı Şekil 1 ve Şekil 2'de görülmektedir.

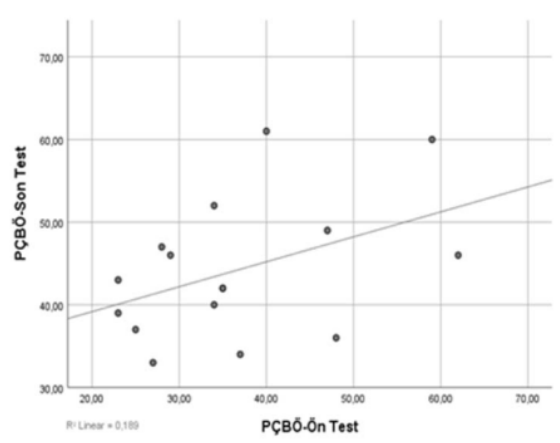

Şekil 1. Deney Grubu PÇBÖ Ön Test ve Son Test Puanları Arasındaki Doğrusal ilişkiyi Gösteren Saçılma Diyagramı

Şekil 1 incelendiğinde deney grubu ön test ve son test puanları arasında doğrusal bir ilişki olduğu görülmektedir.

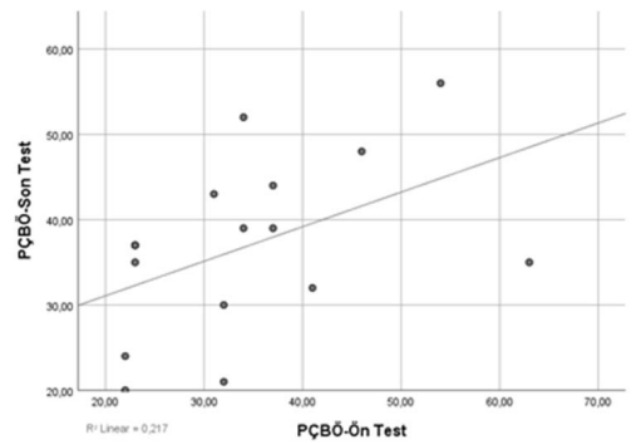

Şekil 2. Kontrol Grubu PÇBÖ Ön Test ve Son Test Puanları Arasındaki Doğrusal iliş̧kiyi Gösteren Saçılma Diyagramı

Şekil 2 incelendiğinde kontrol grubu РÇBÖ ön test ve РÇBÖ son test puanları arasında doğrusal bir ilişki olduğu görülmektedir.

Tablo 7.

Regresyon Eğilimlerinin Homojenliği

\begin{tabular}{lccccc}
\hline Varyansın Kaynağı & Kareler Toplamı & Sd & Kareler Ortalaması & F & p \\
\hline Grup & 41.262 & 1 & 41.262 & .529 & .474 \\
Ön Test PÇBÖ & 103.783 & 1 & 103.783 & 1.330 & .259 \\
Grup X Ön-PÇBÖ & 61.598 & 2 & 30.799 & .395 & .678 \\
Hata & 2028,327 & 26 & 78.013 & & \\
Toplam & 55775.0 & 32 & & \\
\hline
\end{tabular}

ANCOVA analizini uygulayabilmek için gerekli olan son varsayım regresyon eğilimlerinin homojenliğidir. Tablo 7'de sunulan regresyon eğilimi testi sonuçlarına göre, etkileşim ifadesinin (Grup X Ön-PÇBÖ) anlamlılık değerinin .678 olduğu görülmektedir. Regresyon eğilimlerinin homojenliği varsayımının sağlamamız için bu değerin .05 anlamlılık değerinden büyük çıkması gerekmektedir. Elde ettiğimiz bulguda bu değerin .05 anlamlılık değerinden büyük olduğu bu nedenle de regresyon eğilimlerinin homojenliği varsayımı sağlanmaktadır. Tüm varsayımlar sağlandıktan sonra, deney ve 
kontrol gruplarının РÇBÖ ön test puanları kontrol altına alındığında PÇBÖ son test puanları arasında anlamlı bir farklılık olup olmadığını belirlemek için ANCOVA analizi yapılııışır.

Araştırmada deney grubunun ön test, son test ve kalıcılık testinden elde edilen puanlar arasında anlamlı farkın olup olmadığını incelemek için Tek Faktörlü Tekrarlanan Ölçümlerde ANOVA testi kullanılmıştır. Büyüköztürk (2017), sadece zamana bağlı bir değişmenin anlamlı olup olmadığının incelenmek istendiği durumlarda Tek Faktörlü Tekrarlanan Ölçümler için ANOVA testinin kullanılabileceğini ifade etmiştir. Son olarak deney grubundaki çocukların "РС̧ВÖ" son test ve kalıcılık testinden elde ettikleri puanlar ise normal dağılım gösteren gruplar için Illişkili Örneklemler T Testi ile analiz edilmiştir. Iliş̧kili Örneklemler T Testi sadece bir gruptan iki farklı durum veya zamanda toplanan verilerin olduğu durumda kullanılmaktadır. Ön test ve son test veya son test ve kalıclık testi durumları bu tekniğin kullanıldığı durumlara örnek olarak verilebilir (Pallant, 2017).

\section{Bulgular}

Araştırmanın bu bölümünde, araştırma kapsamında toplanan verilerin analiz edilip araştırmanın alt problemleriyle birlikte tablolar halinde sunulmuştur.

Alt Problem 1: Deney ve kontrol grubunu oluşturan çocukların "РÇBÖ" ön test puanlarına göre düzeltilmiş "РÇBÖ" son test puanlarının ortalamaları arasında anlamlı düzeyde fark var mıdır?

Deney ve kontrol gruplarının PÇBÖ ön test puanlarına göre düzeltilmiş $\mathrm{PÇBÖ} \mathrm{son} \mathrm{test} \mathrm{puanları}$ arasında anlamlı bir farkııık olup olmadığını belirlemek için ANCOVA analizi yapılmıştır. Analize ilişkin bulgular Tablo 8'de sunulmuştur.

Tablo 8.

Ön Teste Göre Düzeltilmiş PÇBÖ Son Test Ortalama Puanlarına Göre ANCOVA Sonuçları

\begin{tabular}{|c|c|c|c|c|c|c|c|}
\hline $\begin{array}{c}\text { Varyansın } \\
\text { Kaynağı }\end{array}$ & $\begin{array}{l}\text { Kareler } \\
\text { Toplamı }\end{array}$ & Sd & $\begin{array}{c}\text { Kareler } \\
\text { Ortalaması }\end{array}$ & $\mathbf{F}$ & $p$ & Kısmi n2 & Gözlenen Güç \\
\hline Ön-PÇBÖ & 539.339 & 1 & 539.339 & 7.480 & .011 & .205 & .572 \\
\hline Grup & 336.760 & 1 & 336.760 & 4.670 & .039 & .139 & .538 \\
\hline Hata & 2091.108 & 29 & 72.107 & & & & \\
\hline Toplam & 2967.207 & 31 & & & & & \\
\hline
\end{tabular}

Tablo 8'e bakıldığında deney ve kontrol grubunun düzeltilmiş son test PÇBÖ ortalama puanları arasında anlamlı düzeyde farklııı çıkmıştır $(F(1-29)=4.670, p<.05$, kısmi eta kare $=.139)$. Elde edilen bu bulguya göre, deney grubundaki çocukların son testte problem çözme beceri puanlarının, kontrol grubundaki çocuklara göre daha yüksek olduğu söylenebilir.

Alt Problem 2: Deney grubundaki çocukların "РÇBÖ" ön test, son test ve kalıcılık puanları arasında anlamlı düzeyde farklıık var mıdır?

Deney grubunda ön test-son test-kalıılık testlerinin farklılaşıp farklılaşmadığını belirlemek için tek faktörlü tekrarlanan ölçümler için ANOVA kullanılmıştır. Bu ölçeklerden alınan puanların deney grubunda ön test, son test ve kalııılık testlerine göre farklılaşıp farklılaşmadığına ilişkin yapılan Friedman Testi sonucu Tablo 9'da verilmiştir.

Tablo 9.

Deney Grubunda Ön Test, Son Test ve Kalıclık Testlerine Ilişkin Anova Testi Sonucu

\begin{tabular}{lcccccc}
\hline Varyansın Kaynağı & KT & sd & KO & F & p & Etki Büyüklüğü \\
\hline Deneklerarası & 2565.250 & 15 & 171.017 & & & \\
Ölçüm & 519.292 & 2 & 259.646 & 4.421 & $.00^{*}$ & .906 \\
Hata & 1765.375 & 30 & 58.846 & & & \\
Toplam & 4849.917 & 47 & & & & \\
\hline${ }^{*} p<.05$ & & & & & &
\end{tabular}


DEMIREL \& DERETARLA GÜL- Çukurova Üniversitesi Eğitim Fakültesi Dergisi, 50(2), 2021, 721-748

Tablo 9'a göre, deney grubundaki çocukların ölçme puanlarına ilişkin tekrarlı ölçümler arasında istatistiksel olarak anlamlı bir farklılık olduğu görülmüştür $(F(2,30)=4.421, p<0,05$, kısmî $\eta 2=.906)$. Bu farklılıkların hangi ölçümler arasında olduğunun belirlenmesi için yapılan Bonferroni karşılaştırma testi sonucunda ön test ile son test, ön test ile kalıcılık testi puanlarının ortalamaları arasında anlamlı bir farklılık görülmüştür.

Alt Problem 3: Deney grubundaki çocukların “РС̧ВÖ” son test-kalıcılık testi puanları arasında anlamlı düzeyde fark var mıdır?

Deney grubuna ilişkin son test ve kalıcılık testi arasındaki farkın istatistiksel olarak anlamlı farklılık olup olmadığını test etmek için parametrik yöntemlerden olan İlişkili Örneklemler için T Testi uygulanmış ve elde edilen bulgulara Tablo 10 'da yer verilmiştir.

Tablo 10.

Deney Grubundaki Çocukların PÇBÖ Son Test ve Kalıcılık Testi Puan Ortalamalarına Ait ilişkili Örneklemler için T Testi Sonuçları

\begin{tabular}{lllllll}
\hline Deney Grubu & $\mathbf{N}$ & $\overline{\mathbf{X}}$ & SS & SD & t & $\mathbf{p}$ \\
\hline Son Test & 16 & 44.19 & 2.08 & 9.34 & .589 & .565 \\
\cline { 1 - 4 } Kalıcılık Testi & 16 & 42.81 & 2.19 & & & \\
\hline
\end{tabular}

Tablo 10 incelendiğinde, deney grubundaki çocukların РÇBÖ son test puan ortalamalarının 44.19, kalıcılık testi puan ortalamalarının ise $\mathbf{4 2 . 8 1}$ olduğu görülmektedir. Ayrıca çocukların PÇBÖ son test ve kalıcılık testi puan ortalamaları arasında anlamlı fark olmadığı görülmüştür [t $(9.34)=.589, p>.05)]$.

\section{Tartışma ve Sonuç}

Bilmecelerin 57-66 aylık çocukların problem çözme becerisine etkisinin araştırıldığı bu araştırmada, toplanan verilerin analizi için ANCOVA testi ve illişkili Ölçümler İçin T Testi kullanılmıştır. Çalışma grubunda yer alan deney ve kontrol grubundaki çocukların PÇBÖ’den aldıkları ön test puanları arasındaki farkın istatistiksel olarak anlamlı farklılık yaratmadığı bulunmuştur ( $P>.05)$. Uygulama bitiminde elde edilen son test puanları incelendiğinde, deney grubunun PÇBÖ son test ortalama puanlarının kontrol grubunun РÇВÖ son test puanlarından yüksek bir değerde olduğu görülmüştür. Aynı zamanda grupların ön test puanlarına göre düzeltilmiş son test puanları ANCOVA analizi ile analiz edilmiş, iki grup arasından deney grubunun lehine anlamlı farklılık çıkmıştır $(p<.05)$. Bu farklılığın, deney grubuna uygulanan bilmece etkinliklerinden kaynaklandığı ve elde edilen bu bulguya bağlı olarak bilmece etkinliklerinin 5766 aylık çocukların problem çözme becerisi üzerinde olumlu yönde etkili olduğu ve çocukların problem çözme becerisini geliştirdiği söylenebilir.

Araştırma sonucu elde edilen bu bulgularda, kullanılan bilmece etkinlikleri planlanırken MEB 2013 Okul Öncesi Eğitimi Programında yer verilen bilişsel gelişim alanına ait kazanımlardan problem çözme becerisi ile ilgili olan kazanımların temel alınmasının etkili olduğu düşünülmektedir. Etkinliklerde bilmeceler, çocuklara çözmeleri gereken bir problem olarak sunulmuş ve ardından bir problem süreci eşliğinde bilmecenin cevabına ulaşılmıştır. Hacısalihoğlu-Karadeniz (2019), "Kraliçeyi Kurtarmak" kitabında yer alan bilmecelerin aynı zamanda problem çözme becerisi ile ilişkili olduğunu ve problem çözme stratejileri bağlamında bilmecelerin kullanılabileceğini ifade etmiştir.

Jirata (2012) bilmecelere ilişkin, 7 ve 14 yaşları arasında çocukların görüşlerini aldığı bir çalışmasında çocukların, bilmecenin eğlenceli bir yarış olmasının yanı sıra eğitici avantajlarının da olduğunu belirtiklerini söylemiştir. Çocuklar bilmecelerin hafızalarını harekete geçirdiğini ve problem çözme yeteneklerini geliştirmelerine yardımcı olduğunu ifade etmişlerdir. Solesa-Grijak (2011) 4-6 yaş arasındaki 150 çocuk ile yürüttüğü bir çalışmasında bilmeceleri küçük çocukların tercih ettikleri bir tür sözlü problem olarak ifade etmiştir. Çalışmada bilişsel gelişimin, bilmeceleri sözlü problem olarak çözmedeki etkisini incelemiş ve araştırma sonucunda yaş grubu arttıkça çocukların basit metaforlar 
DEMIREL \& DERETARLA GÜL- Çukurova Üniversitesi Eğitim Fakültesi Dergisi, 50(2), 2021, 721-748

içeren bilmeceleri çözmede daha başarılı olduklarını ve dil gelişimi ile bilişsel gelişimin paralel olduğu sonucuna ulaşılmıştır.

Tanrıkulu (2014) bilmeceyi çocuklar için asıl ilgi çekici hale getiren durumun aslında içlerindeki problem çözme isteği olduğunu belirtirken şimşek (2004) de bilmecelerin çocukta, problem çözme yeteneğini geliştirerek zihinsel gelişimi hızlandırmakla birlikte içinde yer alan mecaz ve sembolleri çözümleyerek ipuçlarından faydalanarak sonuca gidebilmeyi öğrettiğini belirtmiştir. Bu araştırmada bilmece etkinlikleri planlanırken kullanılan bilmecelerin çocukların ilgilerini çekebilecek bir planlamayla beraber bir problem çözme sürecinden geçerek bulmaları sağlanmıştır. Etkinliklerde o gün yer verilen bilmece ne ise onunla alakalı olarak ipuçları hazırlanarak, çocukların bilmecede yer alan mecazları çözerek bilmecenin cevabına ulaşabilmeleri desteklenmiştir.

Çobanoğlu (2017) çalışmasında ilkokul ikinci sınıf matematik dersi kapsamında yer verilen bazı konuların öğretiminde bilmecelerden yararlanılmasının öğrenci başarısı, matematiğe yönelik tutum ve bilgilerin kalıcılığına etkisini incelemiştir. Çalışma sonucunda bilmecelerin ilkokul öğrencilerinin başarısı, matematiğe karşı tutumları ile bilgilerin kalıcılığı üzerinde olumlu etkisinin görüldüğünü ifade etmiştir. Bu araştırmada da benzer şekilde deney grubuna ilişkin ön test ve son test puanları ile ön test ve kalıcılık testi arasında anlamlı fark çıkması problem çözme becerisi üzerinde bilmecelerin etkisinin olduğunu ve bu süre içinde bu etkinin devam ettiğini göstermiştir $(p<.05)$. Araştırmadan elde edilen bulgular ışığında, bilmece etkinliklerinin çocukların problem çözme becerisi üzerinde etkili olduğu bulgusuna ulaşımasında; çocukların bilmecenin cevabına ulaşma sürecinde aynı zamanda bir problem çözme sürecinden geçmeleri sağlanmıştır. Çocuklar bu süreçte kendilerine sunulan farklı bilmecelerin cevaplarına ulaşırken farklı düşünme ve akıl yürütme süreçlerinden geçmişlerdir.

MEB 2013 Okul Öncesi Eğitimi Programında Türkçe etkinlikleri kapsamında yer verilen etkinliklerden biri olan bilmecelere bu çalışmada da temelde Türkçe etkinlikleri olarak bütünleştirilmiş etkinlik halinde yer verilmiştir. Birgül ve Akyol (2018), bir çalışmalarında Türkçe etkinlikleri kapsamında yer verilen etkinliklerin 60-69 aylık çocukların farklı çözüm yolları aramalarını desteklediğini ve problem çözme becerilerini geliştirdiği sonucuna ulaşmışlardır. Bu araştırma sonucunda elde edilen bulgularda bu düşünceyi desteklemektedir.

Araştırma sonucundan hareketle uygulamaya ve ileride yapılması planlanan araştırmalara yönelik öneriler aşağıda sunulmuştur.

\section{Uygulamaya Yönelik Öneriler}

1. Araştırma sonucunda bilmece etkinliklerinin problem çözme becerisi üzerinde etkili olduğu görülmüştür. Bu bağlamda okul öncesi eğitim sürecinde çocukların problem çözme becerilerini geliştirmek için bilmecelere etkinliklerde yer verilmesi desteklenmelidir.

2. Araştırma sonucunda elde edilen verilerden biri bazı ebeveynlerin çocuklarına bilmece sormadıkları olmuştur. Bu bağlamda öğretmenler tarafından aile katııı etkinliği olarak bilmecelere yer verilmiş etkinlik planlamaları yapılabilir.

3. Araştırma sonucunda öğretmenler, bilmecelere hikâye öncesi geçiş etkinliği olarak veya o gün yer verdikleri konu ile ilgili bilmece sorduklarını belirtmişlerdir. Bu bağlamda öğretmenlere, araştırmacılar tarafından farklı konulara ait bilmece etkinlikleri içeren bir etkinlik kitabı hazırlanabilir.

\section{Yapılacak Araştırmalara Yönelik Öneriler}

1. Araştırmada 57-66 aylık çocuklarla çalışılmıştır. Yapılacak çalışmalar diğer yaş gruplarındaki çocuklarla yürütülebilir.

2. Araştırmada uygulama süreci yalnızca 57-66 aylık çocuklarla yürütülmüştür. Yapılacak çalışmalarda uygulama sürecine aktif olarak ebeveynler ve öğretmenler dahil edilebilir. 
DEMIREL \& DERETARLA GÜL- Çukurova Üniversitesi Eğitim Fakültesi Dergisi, 50(2), 2021, 721-748

3. Araştırmada bilmecelerin yalnızca problem çözme becerisi üzerindeki etkisi incelenmiştir. Yapılacak çalışmalarda bilmecelerin problem çözme becerisiyle birlikte dil gelişimi ve yaratıcı düşünme becerisine etkisi incelenebilir.

4. Deneysel olarak planlanan bu çalışma ile çocukların süreç içerisinde problem çözme becerileri yalıızca ölçek sonuçlarına bağlı olarak değerlendirilmiştir. Yapılacak çalışmalarda çocukların süreç içerisinde problem çözme becerilerinin nasıl geliştiği araştırmacılar tarafından yapılacak sınıf içi gözlemlerle, öğretmen ve ebeveynlerle yapılabilecek görüşmelerle incelenebilir.

\section{Araştırmanın Etik İzni}

Yapılan bu çalışmada "Yükseköğretim Kurumları Bilimsel Araştırma ve Yayın Etiği Yönergesi" kapsamında uyulması belirtilen tüm kurallara uyulmuştur. Yönergenin ikinci bölümü olan "Bilimsel Araştırma ve Yayın Etiğine Aykırı Eylemler" başlığı altında belirtilen eylemlerden hiçbiri gerçekleştirilmemiştir.

\section{References}

Abraham, R. D. \& Dundes A. (2007). “Bilmeceler” (Çev: Ezgi Metin). Millî Folklor, 19 (73), 118-126.

Alan, Ü. (2019). Okul öncesi eğitimin ilkeleri. A. Yıldırım (Ed.), Erken çocukluk eğitimine giriş (1. Baskı) içinde (s. 20-48). Ankara: Pegem Yayıncılık.

Altun, D. \& Tantekin Erden, F. (2016). Okul öncesi öğretmen adaylarının erken okuryazarlık ile ilgili görüşleri ve staj uygulamaları. Journal of Kirsehir Education Faculty, 17(1), 241-261

Altunbay, A. G. M. (2014). Yaratıcı ve çağrışımsal düşünmeyi geliştirmesi bakımından Türk halk bilmeceleri. Türklük Bilimi Araştırmaları, 35(1), 11-29.

Baker, G. (2017). 'Do you get it?'An investigation into the different types of ambiguity English-speaking children (aged 6-11) are able to comprehend in verbal riddles. Unpublished Doctoral dissertation, Cardiff University, United Kingdom.

Balta, E. E. (2013). Bilmecelerin dil-düşünme bağlamında eğitimdeki yeri ve önemi. Electronic Turkish Studies, 8(1), 891-899.

Belanger, H. G., Kirkpatrick, L. A., \& Derks, P. (1998). The effects of humor on verbal and imaginal problem solving. Humor-International Journal of Humor Research, 11(1), 21-31.

Binsted, K., Pain, H. \& Ritchie, G. D. (1997). Children's evaluation of computer-generated punning riddles. Pragmatics \& Cognition, 5(2), 305-354.

Birgül, A. E. \& Akyol, A. K. (2018). Türkçe etkinliklerinin anasınıfına devam eden çocukların gelişimlerine etkisinin incelenmesi. Uludağ Üniversitesi Eğitim Fakültesi Dergisi, 31(2), 709-730.

Büyüköztürk, Ş. (2017). Sosyal bilimler için veri analizi el kitabı (23. bs.). Ankara: Pegem Akademi.

Büyüköztürk, Ş., Kılıç-Çakmak, E., Akgün, Ö.A., Karadeniz, Ş. \& Demirel, F. (2012). Bilimsel araştırma yöntemleri (7. Baskı). Ankara: Pegem Akademi.

Büyüköztürk, Ş. (2010). Sosyal bilimler için veri analizi el kitabı. İstatistik, araştırma deseni SPSS uygulamaları ve yorum (11. Baskı). Ankara: Pegem A Yayıncılık.

Çelebioğlu, A. \& Öksün, Y. Z. (1995). Türk bilmeceler hazinesi. İstanbul: Kitabevi Yayınları.

Çobanoğlu, M. (2017). illkokul matematik derslerinde bilmece kullanımının öğrencilerin başarı, tutum ve kalıcılık düzeyine etkisi. Yayınlanmamış Yüksek Lisans Tezi, Adnan Menderes Üniversitesi, Sosyal Bilimler Enstitüsü, Aydın.

Dewi, D. A. D., \& Bektiarso, S. (2017). Pengaruh model pembelajaran problem based ınstruction disertai metode pictorial riddle terhadap hasil belajar dan kemampuan berpikir kritis siswa pada mata pelajaran fisika di sma. Jurnal Pembelajaran Fisika, 6(1), 48-55. 
DEMIREL \& DERETARLA GÜL- Çukurova Üniversitesi Eğitim Fakültesi Dergisi, 50(2), 2021, 721-748

Doolittle, P.E. (1995) Understanding cooperative learning through Vygotsky. In Lily National Conference on Excellence in College Teaching, SC, June 2-4, Colombia.

Dowling, M. (2005). Young Children's Personal, Social and Emotional Development. London: Paul Chapman.

Ely, R. \& McCabe, A. (1994). The language play of kindergarten children. First Language, 14(40), 19-35.

Erdoğan, T., Altınkaynak, Ş. Ö. \& Erdoğan, Ö. (2013). Okul öncesi öğretmenlerinin okuma-yazmaya hazırlığa yönelik yaptıkları çalışmaların incelenmesi. Ilkogretim Online, 12(4), 1188-1199

Ergişi, A. (2014) Türkçe etkinliklerinin anasınıfına devam eden çocukların gelişimlerine etkisinin incelenmesi. Yayınlanmamış Doktora Tezi, Ankara Üniversitesi Fen Bilimleri Enstitüsü. Ankara

Erkan, Ş. (2015). Bilmecelerle yabancı dil eğitimi. Eğitim ve Öğretim Araştırmaları Dergisi, 2(4), 200-209.

Ersoy, O. (1986). Okul öncesi dönemde kitabın önemi. Türk Kütüphaneciliği, 35(2), 3-6.

Ezell, H. K. \& Jarzynka, M. A. (1996). An intervention for enhancing children's understanding of jokes and riddles. Child Language Teaching and Therapy, 12(2), 148-163.

Field, A. (2009). Discovering statistics using SPSS (and sex and drugs and rock ' $n$ ' roll) (Third edition). London: SAGE Publications Ltd

Firestien, R. L. \& McCowan, R. J. (1988). Creative problem solving and communication behavior in small groups. Creativity Research Journal, 1(1), 106-114.

Goldstein, J. H., Harman, J., McGhee, P. E., \& Karasik, R. (1975). Test of an information-processing model of humor: Physiological response changes during problem-and riddle-solving. The Journal of general psychology, 92(1), 59-68.

Gönen, M., Ünüvar, P., Bıçakçı, M., Koçyiğit, S., Yazıcı, Z., Orçan, M., Aslan, D., Güven, G., \& Özyürek, A. (2010). Okul öncesi eğitim öğretmenlerinin dil etkinliklerini uygulama biçimlerinin incelenmesi. Mehmet Akif Ersoy Üniversitesi Eğitim Fakültesi Dergisi, 10 (19), 23-40.

Guo, J., Zhang, X., Wang, Y., \& Xeromeritou, A. (2017). Humour among Chinese and Greek preschool children in relation to cognitive development. International Electronic Journal of Elementary Education, 3(3), 153-170.

Hayran, Z. (2010). Çok uyaranlı eğitim ortamlarının öğrencilerin kavram gelişimine etkisi. Eğitim ve Bilim, 35(158), 128-142.

Himah, E. F., Bektiarso, S. \& Prihandono, T. (2015). Penerapan model problem based learning (pbl) disertai metode pictorial riddle dalam pembelajaran fisika di sma. Jurnal Pembelajaran Fisika, 4(3), 216-267.

Kabadayı, A. (2007). Sosyal bir ders materyali olarak bilmecelerin çocukların gelişim alanlarına katkılarının incelenmesi: Konya Örneği. Uluslararası İnsan Bilimleri Dergisi, 4(2), 1-17.

Kandır, A. \& Alpan, U. Y. (2008). Okul öncesi dönemde sosyal-duygusal gelişime anne-baba davranışlarının etkisi. Sosyal Politika Çalışmaları Dergisi, 14(14), 33-38.

Karadeniz, M. H. (2018, Ekim-Kasım). "Kraliçeyi kurtarmak" adlı hikâye kitabında yer alan bilmecelerin problem çözme stratejileri bağlamında incelenmesi. 4. Uluslararası Akademik Araştırmalar Kongresi'nde sunulan bildiri. Selçuk Üniversitesi, Konya.

Karayazı, N. \& Karakuş, N. (2018). Kelime öğretimi açısından bilmecelerin yeri: küçükler gazetesi örneği. Motif Akademi Halkbilimi Dergisi, 11(24), 108-123.

Katrancı, M. (2018). Erken çocukluk eğitimi ve önemi. S. Seven (Ed.), Erken çocukluk eğitimine giriş (4. Baskı) içinde (s. 2-15). Ankara: Pegem Yayıncılık

Keleş, M. (2007). Orta öğretim Türk dili ve edebiyatı derslerinde bilmecenin öğretim aracı olarak kullanılma biçim ve düzeyleri. Yayınlanmamış Yüksek Lisans Tezi, Çanakkale Onsekiz Mart Üniversitesi Sosyal Bilimler Enstitüsü, Çanakkale. 
DEMIREL \& DERETARLA GÜL- Çukurova Üniversitesi Eğitim Fakültesi Dergisi, 50(2), 2021, 721-748

Kılıçarslan, R. (2015). Çocuk edebiyatında bilmecenin yeri ve bir bilmece derleme çalışması. International Journal of Language Academy. 3(4), 129-140.

Korovkin, S. \& Nikiforova, O. (2015). Humor as a facilitator of insight problem solving. In Eapcogsci.

Lee, M. F. (2019). The influence of interesting riddles into English teaching in junior high schools on students' English performance, positive and negative emotions and sense of humor. Doctoral dissertation, National Taiwan Normal University. Taiwan.

Mai, X. Q., Luo, J., Wu, J. H. \& Luo, Y. J. (2004). “Aha!" effects in a guessing riddle task: An event-related potential study. Human brain mapping, 22(4), 261-270.

Masfuah, S. (2016). Pictorial riddle melalui pembelajaran attention, relevance, confidence, satisfaction (arcs) untuk meningkatkan kemampuan pemecahan masalah dan motivasi berprestasi siswa. Jurnal Konseling GUSJIGANG, 2(1).

MEB (2013). Okul Öncesi Eğitim Programı. Ankara: Meb Basımevi.

MEGEP (2016) Çocuk gelişimi ve eğitimi: Türkçe dil etkinlikleri. Erişim Tarihi: 16.11.2020, http://megep.meb.gov.tr/mte_program_modul/moduller/T\%C3\%BCrk\%C3\%A7e\%20Etkinlikleri.pdf

Mert, E. (2012). Anadili eğitimi-öğretimi sürecinde çocuk yazını ürünlerinden yararlanma ve masal türüne yönelik bazı belirlemeler. Pamukkale Üniversitesi Eğitim Fakültesi Dergisi, 31(31), 1-12.

Montalvo Castro, J. (2011). Adivinanzas audiovisuales para ejercitar el pensamiento creativo infantil. Comunicar: Revista Científica de Comunicación y Educación, 18(36), 123-130.

Motroni, E. R. (2016). Home language questionnaires as a means of investigating the impact of diverse experiences on cognitive and linguistic performance in elementary-aged children. Unpublished Doctoral dissertation, MGH Institute of Health Professions.

Oğuz, V. \& Köksal- Akyol, A. (2015). Problem Çözme Becerisi Ölçeği (PÇBÖ) geçerlik ve güvenirlik çalışması. Çukurova Üniversitesi Eğitim Fakültesi Dergisi, 44(1), 105-122.

Oktay, A. (2007). Yaşamın sihirli yılları: okul öncesi dönem (6. baskı). İstanbul: Epsilon Yayıncılık.

Oruç, M. (2011). Bilmecelerin kelime öğrenimine etkisi (Hatay ili Dörtyol ilçesi Yeniyurt ilköğretim okulu örneği). Yayınlanmamış Yüksek Lisans Tezi, Kilis 7 Aralık Üniversitesi, Kilis.

Özkara, Y. (2013). İlköğretim Türkçe eğitimi sürecinde mizah unsurlarından yararlanma. Milli Folklor, 25(100), 182-188.

Pallant, J. (2017). SPSS kullanma kılavuzu (Çev. Sibel, Balcı ve Berat, Ahi.). (2. Baskı) Ankara: Nobel Yayınları.

Pepicello, W. J. (1989). Ambiguity in verbal and visual riddles. Humor-International Journal of Humor Research, 2(3), 207-216.

Ruiz Gurillo, L. (2017). El evidencial con humor entra. Acerca de su uso en los monólogos humorísticos. Normas, 7(2), 5-18.

Smullyan, R. (1978). What is the name of this book. Prentice-Hall, NJ.

Solesa-Grijak, D. (2011). Cognition and metalinguistic awareness as sine quibus non for solving verbal problems. Studia Psychologica, 53(1), 41-52.

Stefanova, A. (2007). Riddles as a community psychological phenomenon in folklore: myths, fairytales, personal literature art. Folklore: Electronic Journal of Folklore, 35(1), 131-142.

Sutton-Smith, S. A. (1976). Developmental structural account of riddles. In: B. Kirschenblatt-Gimblett (ed.), Speech play. Philadelphia, Pa.: University of Pennsylvania Press.

Şimşek, T. (2004). Çocuk Edebiyatı. Ankara: Rengârenk Yayınları. 
DEMIREL \& DERETARLA GÜL- Çukurova Üniversitesi Eğitim Fakültesi Dergisi, 50(2), 2021, 721-748

Taner Derman, M., Ergişi Birgül, A. \& Şahin Zeteroğlu, E. (2019). Farklı tekniklerle sunulan türkçe dil etkinliklerinin 48-60 aylık çocukların dil gelişimlerine etkisinin incelenmesi. Electronic Turkish Studies, 14(1), 667-680.

Tanrıkulu, F. (2014). Medya okuryazarlığı bağlamında çocuk dergileriyle zenginleştirilmiş türkçe dersinin etkililiği: bir eylem araştırması. Yayınlanmamış Doktora Tezi, Çanakkale Üniversitesi Eğitim Bilimleri Enstitüsü, Çanakkale.

Taşkın, N. \& Tuğrul, B. (2014). Okul öncesindeki çocukların dil ile matematik becerileri arasındaki ilişkinin farklı değişkenlere göre incelenmesi. Yüzüncü Yıl Üniversitesi Eğitim Fakültesi Dergisi, 11(1), 129-148.

Tepetaş-Cengiz, Ş. Kılınç, F.E. \& Tezcan, T. (2018). Okul öncesi öğretmenlerinin kullandıkları türkçe etkinlikleri ve bu etkinliklerin uygulanmasına yönelik görüşlerinin incelenmesi. International Journal of Languages' Education and Teaching, 6(3), 481-498.

Tezbaşaran, A. (1997). Likert tipi ölçek geliştirme kılavuzu (ikinci baskı). Türk Psikologlar Derneği Yayını, Ankara.

Tuğrul, B., Aslan, Ö. M., Ertürk, G. \& Altınkaynak, Ş. Ö. (2014). Anaokuluna devam eden altı yaşındaki çocuklar ile okul öncesi öğretmenlerinin oyun hakkındaki görüşlerinin incelenmesi. İnönü Üniversitesi Eğitim Fakültesi Dergisi, 15(1), 97-116.

Van Dooren, W., Lem, S., De Wortelaer, H. \& Verschaffel, L. (2019). Improving realistic word problem solving by using humor. The Journal of Mathematical Behavior, 53(1), 96-104.

Waithaka, E. N. (2017). Choice of the Medium of Instruction in Kenyan Preschools: Averting Xenocentrism. Journal of Education and Practice, 8(9), 210-216.

Whitt, J. K. \& Prentice, N. M. (1977). Cognitive processes in the development of children's enjoyment and comprehension of joking riddles. Developmental Psychology, 13(2), 129.

Yangil, M. K. \& Kerimoğlu, C. (2014). Bilmecelerin eğitimdeki yeri ve önemi. Eğitim Bilimleri Araştırmaları Dergisi, 4(2), 341-354.

Yılmaz, F. \& Taşkın, M. (2014). Hacivat karagöz oyunları ile türkçenin yabancı dil olarak öğretimi ve kültür aktarımı. Akademik Sosyal Araştırmalar Dergisi, 2(5), 270-288

Yuill, N. (2009). The relation between ambiguity understanding and metalinguistic discussion of joking riddles in good and poor comprehenders: Potential for intervention and possible processes of change. First language, 29(1), 65-79. 